UC-48

Issued: October 1982

$L A_{2}--9528$

DE83 003892

\title{
Life Span of C57 Mice as Influenced by Radiatión Dose, Dose Rate, and Age at Exposure
}

\author{
J. F. Spalding \\ A. G. Thomas \\ G. L. Tietjen
}

\section{MOTICE}

PORTIONS OF THIS REPORT ARE ILLEGIBLE. It ms been roproduced from the best available copy to permit the hroadest possible availAntings.

TH OSTI

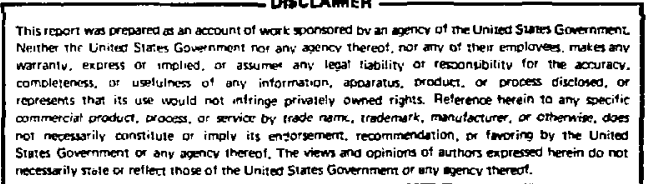

Contepcr $*$ w-7\%OS-ENG-36

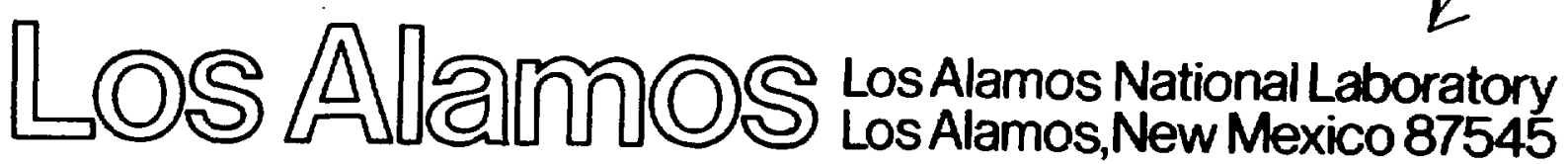




\title{
LIFE SPAN OF C57 MICE AS INFLUENCED BY RADIATION DOSE, DOSE RATE, AND AGE AT EXPOSURE
}

by

J. F. Spalding, R. G. Thomas, and G. L. Tietjen

\begin{abstract}

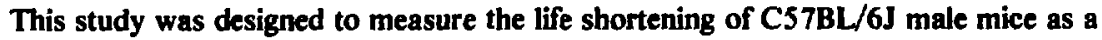
result of exposure to five external doses from ${ }^{60} \mathrm{Co}$ gamma radiation delivered at six different dose rates. Total doses ranged from 20 to 1620 rad at exposure rates ranging from 0.7 to $36000 \mathrm{R} /$ day. The ages of the mice at exposure were newborn, 2, 6, or 15 months. Two replications were completed. Although death was the primary endpoint, we did perform gross necropsies. The life span findings are variable, but we found no consistent shortening compared to control life spans. Therefore, we cannot logically extrapolate life shortening to lower doses, from the data we have obtained. In general, the younger the animals were at the beginning of exposure, the longer their life spans were compared to those of controls. This relationship weakened at the higher doses and dose rates, as mice in these categories tended not to have significantly different life spans from controls. Using life span as a criterion, we find this study suggests that some threshold dosage may exist beyond which effects of external irradiation may be manifested. Up to this threshold, there is no shortening effect on life span compared to that of control mice. Our results are in general agreement with the results of other researchers investigating human and other animal life span effects of irradiation.
\end{abstract}

\section{INTRODUCTION}

Many researchers have studied the radiation-induced effects on life span and considered injuries or diseases induc d by exposure to ionizing radiation. In $1965 \mathrm{~L}$. H. Strong ' referenced 96 publications on the subject; more recently (March 1978) life shortening and late biological effects of exposure to ionizing radiation were reviewed in the proceedings of an International Atomic Energy Agency Symposium in Vienna. ${ }^{2}$ Storer et al. $^{3}$ also referenced much of the literature on radiation-induced life shortening. One fascinating treatise examines the effects of ionizing radiation and hormesis, ${ }^{4}$ defined as the stimulation of any system by subharmful amounts of any agent. This monographt documents the lengthening of life span by using subharmful doses of radiation. Thus, studies on the life span of mammals at low doses and dose rates may yield a variety of findings; our study examines the shortening of life as a function of these radiation variables.

Life shortening, whether it stems from a specific malady such as cancer or an irreparable injury to many life-sustaining cell, tissue, and organ systems, has been generally accepted as one biological endpoint of exposure to ionizing radiation. Because no human or experimental animal data are sufficiently elaborate to 
quantitate the adverse effects from a very low dose or dose-rate exposure, we generally accept that any lifeshortening effects from a large dose and/or dose-rate exposure could be extrapolated to represent the effects that could not be measured experimentally. Research data using life span as the measured endpoint have been compiled at different laboratories by different researchers using several strains or species under a variety of environmental conditions.

Our comprehensive study was designed to eliminate as many variables as feasible, to provide reliable life span data from which reasonable predictions and extrapolations could be made. The original study called for extensive histopathological examination of all tissues, but financial limitations precluded this most important endpoint.

\section{MATERIALS AND METHODS}

Mice used in this study were strain C57BL/6J from the Jackson Laboratory at Bar Harbor, Maine. Over 10 years ago that laboratory reported the mean age at death of this strain was $693 \pm 16$ days for females and $670 \pm$ 20 days for males. ${ }^{5}$ Gross pathology showed the cause of death to be nonspecific, without predominant pattern. Thus, this strain was considered genetically stable. Our study used male mice because female mice are permanently sterilized by relatively small doses of radiation. Sterility of the female from an irreparable disturbance of normal ovarian functions may cause an imbalance and/or diminished levels of ovarian-stimulated hormones. The effects of this permanent hormonal infraction on the incidences of killing diseases are not known. Thus, life reduction from radiation exposure of the female mouse may not be representative in degree or kind for other mammalian species with greater radiation sterility resistance.

A basic $5 \times 6 \times 4$ factorial design was used (Table $I$ ). Five doses $(20,60,180,540$, and 1620 rad) were given at six exposure rates $(0.7,2.1,6.3,18.9,56.7$, and 36000 $\mathrm{R} /$ day) to four age groups (newborn, 2 month, 6 month, and 15 month). Doses and dose rates were both increased by multiples of 3 to be easily interpretable logarithmically. Approximately 25 mice were used per cell-point and, except for the newborn age group, the 180-rad dose group at $18.9 \mathrm{R} /$ day with 2 -month-old mice, and the 180-rad dose group at $0.7 \mathrm{R} /$ day with 15 month-old mice, the experiment was replicated once. To minimize a possible seasonal environment effect, all dose-rate/age combination exposures were started on the same day for each replication.

Newborn mice, obtained by timed matings, were an exception to this plan. Because of budgetary and logistical problems, they were exposed only at dose rates of $0.7,6.3,56.7$, and $36000 \mathrm{R} /$ day (Table I). Although some of the exposures in this age group were started with the first replication of the other three age groups, approximateiy 9 weeks were required to obtain newborn mice to complete the exposure. Dose-rate measurements were made with high-energy Victoreen ionization chambers (2.5- and 100-R chambers calibrated at the National Bureau of Standards). Measured air doses, corrected for temperature and barometric pressure, were converted to tissue doses with the conversion factor $1 \mathbf{R}$ $=0.96 \mathrm{rad}$. During the longer exposure periods required for larger doses at low dose rates, periodic target-tosource adjustments and dose measurements were corrected for radioactive decay of the "Co source.

Seven to nine mice were housed on wood shavings in each box-type transparent polycarbonate plastic cage

TABLE 1. Experimental Protocol for Studying the Ereets of Rediution Dose, Dowe Rere, and Age at Exposure in C57BL/6J Mice"

\begin{tabular}{|c|c|c|c|c|c|}
\hline \multirow{2}{*}{$\begin{array}{l}\text { Age at } \\
\text { Exposure }\end{array}$} & \multicolumn{5}{|c|}{ Done (rad) } \\
\hline & 20 & 60 & 180 & 540 & 1620 \\
\hline Newborn & ACEF & ACE & ACE & CE & C \\
\hline 2 months & ABCDEF & ABCDEF & ABCDEF & DCDEF & CDE \\
\hline 6 months & ABCDEF & ABCDEF & ADCDEF & BCDEF & CDE \\
\hline 15 months & ABCDEF & ABCDEF & ADCDEF & CDIF & DE \\
\hline
\end{tabular}


( $5 \times 8 \times 12$ in.). The mice were provided with RocklandTeklad rodent food and tap water and were checked twice daily 5 days a week and daily on weekends. Cages and water bottles were changed semiweekly. Dead and moribund animals were necropsied and gross causes of death determined witnver possible. Two exposure facilities with point ${ }^{60} \mathrm{Co} \gamma$-ray sources were used for the five lower doses and the $36000 \mathrm{R} /$ day dose rate. The high-dose-rate mice were exposed in ventilated plastic tubes; all other dose-rate exposures (0.7-56.7 R/day) were accomplished in the plastic cages described above.

The 25 control mice per replica age group (Table I) were treated similarly to their irradiated counterparts, but there were some necessary logistical differences. Control mice were not included in the experiment until the age at exposure had been obtained. For example, when a 6-month-old exposure regime began, the corresponding control mice were randomly selected from the shipment received for this group. Control mice were placed in our general housing conditions, whereas the experimental mice receiving chronic irradiation were placed in one of the two ${ }^{60} \mathrm{Co}$ source rooms. After the irradiated animals received their prescribed doses, they were housed alongside the control mice until death. Two dummy exprosure rooms creating exact housing conditions for true control were not feasible, but we might have considered the lowest total dose and dose-rate animal groups as the control groups for comparing life spans and tumor incidences.

We recorded the findings of gross necropsies performed on all animals at death. All grossly appearing abnormal tissues were examined histopathologically, but the scope and cost of complete microscopic analyses were prohibitive. Our findings confirm those of the Jackson Laboratory. The cause of death in this strain (C57BL/6J) is rather nonspecific; no predominant diseases accompany death.

\section{RESULTS}

We designed our study to produce data feasible for curve fitting of dose, dose rate, and age at exposure. We anticipated, from earlier radiation effects studies with rodents, ${ }^{1-3,}$ - -20 that life shortening resulted from wholebody exposure to ionizing radiation and, to some degree, was dose, dose-rate, and age dependent. Our study suggests that although the design assumptions may have been prudent, they were at best unfounded over the wide range of variables. In comparing life span data, the random variable $X$ represents the lifetime of mice given a certain radiation regime. The cumulative distribution function $[F(x)]$ represents the probability of surviving $x$ days or less. The cumulative survival function $[S(x)=1-$ $F(x)\}$ is the probability of surviving more than $x$ days. Because survival functions are standard tools for summarizing survival data, we use them extensively in evaluating these data. The Kaplan-Meier or "productlimit estimates" of $S(x)$ were used because they do not require knowledge of the distributional form of $(x)$. The standard log-rank test, called the Mantel-Cox test by some researchers, was used to test the equality of one or more survival functions. Hypothesis tests were made at the $5 \%$ level of significance.

Table II(A-F) shows median life spans and Fig. I(a)(v) shows survival plots for various total doses given at fixed exposure rates. Table IIA and Fig. 1(a)-(d) reveal the pattern evident throughout most of this experiment. Most of the irradiated animals lived longer or no differently than did the nonirradiated controls; however, in several cases differences were significant. For newborn mice exposed to $180 \mathrm{rad}$ at $0.7 \mathrm{R} /$ day, the life span was significantly longer than it was for controls. At all dose levels the 2-month age group lived significantly longer than did the median controls. Although there were no differences among 6-month-old mice, the 15-month group with the 20-rad dose lived significantly longer than did their controls.

The 2-month age group had the only mice with significantly altered life span at a dose rate of $2.1 \mathrm{R} /$ day [Table IIB and Fig. 1(e)-(g)]. For the newborns exposed at $6.3 \mathrm{R} /$ day [Table IIC and Fig. 1(h)], the survival function for the controls was below that of every exposed group; therefore, a greater proportion of the exposed animals survived for any given length of time. For the 2month group, each dose group is entirely different from the control curve [Fig. 1(i)]. The 20-rad dose for the 2 month group shows strikingly different results from all others. Many deaths between $\mathbf{3 2 0}$ and $\mathbf{4 0 0}$ days in this group were probably due to a competing cause of death, and perhaps these deaths should have been censored (not counted as suitable for determining average life span). For the 6-month group, the controls differed significantly only from the 20-rad dose group, and the same is true for the 15 -month age group. With a dose rate of $18.9 \mathrm{R} / \mathrm{day}$ [Table IID and Fig. 1(I)], the survival curve for the controls lies beneath that of every treated group of 2 month-old mice, with the exception of some points $a$ the 1620-rad dose. For the 6- and 15-month age groups, there were no significant differences between control and irradiated groups [Table IID and Fig. I(m) and (n)]. 


\begin{tabular}{|c|c|c|c|c|c|c|c|c|c|c|c|}
\hline \multirow{2}{*}{$\begin{array}{l}\text { Age at } \\
\text { Exposure }\end{array}$} & \multicolumn{11}{|c|}{ Total Dose (red) } \\
\hline & 0 & 20 & 60 & 180 & 540 & 1620 & 20 & 60 & 180 & 540 & 1620 \\
\hline & & \multicolumn{5}{|c|}{ A. $0.7 \mathrm{R} / \mathrm{d} x \mathrm{y}$} & \multicolumn{5}{|c|}{ B. $2.1 \mathrm{R} / \mathrm{day}$} \\
\hline Newborn & 767 & 830 & 787 & $936^{*}$ & -- & $\overline{-}$ & $\overline{-}$ & - & - & $\cdots$ & - \\
\hline 2 months & 757 & $886^{\circ}$ & 883* & $892^{\circ}$ & --- & --- & $903^{*}$ & $861^{*}$ & $940^{\circ}$ & $967 *$ & - \\
\hline 6 months & 917 & 930 & 941 & 919 & $-\cdots$ & --- & 947 & 923 & 920 & 933 & - \\
\hline \multirow[t]{2}{*}{15 months } & 892 & $964^{*}$ & 904 & 885 & -- & $\cdots$ & 925 & 935 & 924 & - & - \\
\hline & & \multicolumn{5}{|c|}{ C. $6.3 \mathrm{R} / \mathrm{day}$} & \multicolumn{5}{|c|}{ D. $18.9 \mathrm{R} / \mathrm{day}$} \\
\hline Newborn & 767 & 805 & 889 & $892^{*}$ & 868 & 779 & -- & $\ldots$ & - & $\ldots$ & - \\
\hline 2 months & 757 & $598^{*}$ & $879 *$ & $868^{*}$ & $839^{*}$ & 883* & $889^{*}$ & 904* & $877^{*}$ & $837^{*}$ & 769 \\
\hline 6 months & 917 & $996^{*}$ & 919 & 899 & 931 & 918 & 911 & 861 & 934 & 925 & 857 \\
\hline \multirow[t]{2}{*}{15 months } & 892 & $936^{*}$ & 907 & 867 & 872 & --- & 925 & 937 & 929 & 929 & 878 \\
\hline & & \multicolumn{5}{|c|}{ E. $56.7 \mathrm{R} / \mathrm{day}$} & \multicolumn{5}{|c|}{ F. $36000 \mathrm{R} /$ day } \\
\hline Newborn & 767 & $931^{*}$ & 888 & 870 & 769 & -- & 753 & $\ldots$ & $\cdots$ & -- & -- \\
\hline 2 months & 757 & $845^{*}$ & $896^{*}$ & 952* & $847^{*}$ & $588^{*}$ & 881* & 838* & $856^{*}$ & 754 & - \\
\hline 6 months & 917 & $981^{\circ}$ & 917 & 902 & 904 & 898 & 855 & 894 & 835 & 814 & $\ldots$ \\
\hline 15 months & 892 & 918 & 872 & 835 & 927 & 885 & 838 & 796 & 845 & 829 & $\cdots$ \\
\hline
\end{tabular}

Newborn mice in all dose groups with exposures of 56.7 R/day (Table IIE) lived longer than did control animals, but only the 20-rad dose group lived significantly longer. All 2-month dose groups except $1620 \mathrm{rad}$ lived significantly longer than did their controls (Table IIE). The 1620-rad dose group appears to have been severely affected and lived significantly shorter lives than did their controls [Fig. 1(p)]. The 20-rad dose groups lived significantly longer lives than did controls in the first three age groups (Table IIE), but the treated 15-month-old mice did not differ from their controls [Table IIE and Fig. 1(r)]. At the acute exposure rate, $36000 \mathrm{R} /$ day [Table IIF and Fig. I(s)-(v)], newborn mice were exposed to one 20-rad dose and life span for this group was shorter (but not significantly shorter) than it was for the control. The 20-, 60-, and 180-rad dose groups of 2-month mice lived significantly longer lives than did their control mice. No significant differences appear in any of the dose groups in 6- and 15-month-old micc.

Table III(A-E) and Fig. 2(a)-(t) present life span data for a fixed total dose at various rates. The variable given for each exposure-rate combination is the median lifetime of the group as estimated from the survival function, that is, the value of $x$ for which $S(x)=0.50$. In Table IIIA, the data show that for the newborns the controls do not differ from the 0.7 - and $6.3-\mathrm{R} /$ day groups, but the controls differ significantly from the 56.7-R/day group, and the median lifetime of the $36000-\mathrm{R} /$ day group is 14 days shorter than it is for their controls.

For the 2-month-old group, the exposed mice lived longer than did their controls (except for the 6.3-R/day group, which differed significantly from the control group). The string of animals dying between $\mathbf{3 0 0}$ and $\mathbf{4 0 0}$ days [Fig. 2(b)] should have been censored, as we suspect some of them may have died from causes other than radiation exposure. The 6-month-old mice, with the $36000-R /$ day rate lived less time than did the control [Fig. 2(c)]; the median life was shortened 62 days. The $0.7,2.1$, and 18.9 groups do not differ significantly from the controls, but the 6.3- and 56.7-R/day groups border on differing significantly from the controls, living 79 and 64 days longer than controls. For 15-month-old mice, the controls do not differ significantly from the 36000 R/day group [Fig. 2(d)]; the other treated groups have survival curves above the controls.

There are no significant differences amoas the newborn, 6-month-old, or 15-month-old mice a 60-rad total dose kevel [Table IIIB and Fig. 2(e), (s), and (b)]. At the 180-rad dose, the newborn animals lived significantly 
TABLE III. Median Lifetime in Days from Birth versus Radiation Dose Rate and Age at Exposure as a Function of Tota! Dose. ${ }^{\text {D.6 }}$

\begin{tabular}{|c|c|c|c|c|c|c|c|c|c|c|c|c|c|}
\hline \multirow{2}{*}{$\begin{array}{l}\text { Age at } \\
\text { Exposure }\end{array}$} & \multicolumn{13}{|c|}{ Dose Rate (R/day) } \\
\hline & $\mathbf{0}$ & 0.7 & 2.1 & 6.3 & 18.9 & 56.7 & 36000 & 0.7 & 2.1 & 6.3 & 18.9 & 56.7 & 36000 \\
\hline & & \multicolumn{6}{|c|}{ A. $20 \mathrm{rad}$} & \multicolumn{6}{|c|}{ B. $60 \mathrm{rad}$} \\
\hline Newborn & 767 & 830 & -- & 805 & -- & $931^{*}$ & 753 & 787 & $\cdots$ & 889 & - & 888 & - \\
\hline 2 months & 757 & $886^{*}$ & 903* & $598^{*}$ & 889* & $845^{*}$ & 881* & 883* & $861^{*}$ & 879* & $904^{*}$ & $896^{*}$ & 838* \\
\hline 6 months & 917 & 930 & 947 & $996^{\circ}$ & 911 & $981^{*}$ & 855 & 941 & 923 & 919 & 861 & 917 & 894 \\
\hline \multirow[t]{2}{*}{15 months } & 892 & $964^{\circ}$ & 925 & $936^{*}$ & 925 & 918 & 838 & 904 & 935 & 907 & 937 & 872 & 796 \\
\hline & & \multicolumn{6}{|c|}{ C. $180 \mathrm{rad}$} & \multicolumn{6}{|c|}{ D. $540 \mathrm{rad}$} \\
\hline Newborn & 767 & $936^{*}$ & .- & $892^{*}$ & $-\ldots$ & 870 & $\ldots$ & -- & $\ldots$ & 868 & $\ldots$ & 769 & -- \\
\hline 2 months & 757 & $892^{\circ}$ & $940^{4}$ & $868^{*}$ & $877^{*}$ & $952^{*}$ & $856^{\circ}$ & -- & $967^{*}$ & $839^{*}$ & $837^{*}$ & $847^{*}$ & 754 \\
\hline 6 months & 917 & 919 & 920 & 899 & 934 & 902 & 835 & -- & 933 & 931 & 925 & 904 & 814 \\
\hline \multirow[t]{2}{*}{15 months } & 892 & 885 & 924 & 867 & 929 & 835 & 845 & -.- & -- & 872 & 929 & 927 & 829 \\
\hline & & \multicolumn{6}{|c|}{ E. $1620 \mathrm{rad}$} & & & & & & \\
\hline Newborn & 767 & $\cdots$ & -- & 779 & $\ldots$ & -- & - & & & & & & \\
\hline 2 months & 757 & -- & - & $883^{*}$ & 769 & $588^{*}$ & -- & & & & & & \\
\hline 6 months & 917 & $\cdots$ & $\ldots$ & 918 & 857 & 898 & $\ldots$ & & & & & & \\
\hline 15 months & 892 & -- &.- & -- & 878 & 885 & - & & & & & & \\
\hline
\end{tabular}

The " indicates significant difference from controls at the $5 \%$ level.

The --- indicates no animnls were placed in these groups.

longer lives than did their controls at $0.7-\mathrm{R} /$ day and 6.3$\mathrm{R} /$ day (Table IIIC). For the 2-month-old mice, all the treated animals lived significantly longer lives than did their controls, and the survival curves of irradiated groups are entirely above those of the controls [P < 0.0026) Fig. 2(j)]. For the 6-month- and 15-month-old mice, there are no significant differences between the controls and treated animals [Fig. 2(k) and (l)].

The newborn, 6-, and 15-month-old mice given 540 rad [Table IIID, Fig. 2(m), (o), and (p)] showed no significant differences between controls and treated animals. All the 2-month-old treated animals lived significantly longer lives than did their controls except at $36000 \mathrm{R} /$ day [Fig. 2(n)].

Newborn mice were given 1620 rad [Table IIIE and Fig. 2(q)] at only one exposure rate (6.3 R/day), and their life spans did not differ from those of their controls. The life spans were significantly shorter for 2 -month-old mice at $56.7-\mathrm{R} /$ day dose and significantly longer at 6.3 R/day dose [Fig. 2(r)]. With 6- and 15-month-otd mice there were no differences [Table IIIE and Fig. 2(s) and (t)].
Table IV shows life spans as mean values instead of medians. Significance tesis were run on the means as if the data were normally distributed, to compare the two types of significance testing. The t-testing used in Table IV was at a significance level of 0.1 ; the $t$-statistic for mean values signified by the asterisk therefore fell below the 5th percentile or above the 95th percentile of the $t$ distribution. In comparing Tables III and IV we find only one insignificant value in Table III that was not insignificant in Table IV (20 rad, $36000 \mathrm{R} /$ day, 6 months). Altogether, there were 31 values significantly different from controls using medians and the Mantel-Cox method, compared to 23 using t-testing of the data and normal distribution statistics. In each table, of those values differing from the controls, only two groups lived a significantly shorter life span than did their controls (Table III: $20 \mathrm{rad}, 6.3 \mathrm{R} / \mathrm{day}, 2$ months and $1620 \mathrm{rad}$, $56.7 \mathrm{R} /$ day, 2 months; Table IV: $20 \mathrm{rad}, 36000 \mathrm{R} / \mathrm{day}$, 6 months and $1620 \mathrm{rad}, 56.7 \mathrm{R} / \mathrm{day}, 6$ months).

For all age groups, 5 benign and 11 malignant tumors were detected in control animals, whereas 39 benige and 
TABLE IV. Mean Lifetime in Days from Birth versus Radiation Dose Rate and Age at Exposure as a Function of Total Dose"

\begin{tabular}{|c|c|c|c|c|c|c|c|c|c|c|c|}
\hline \multirow[b]{2}{*}{$\begin{array}{l}\text { Age at } \\
\text { Exposure }\end{array}$} & \multicolumn{11}{|c|}{ Total Dose (rad) } \\
\hline & \multirow[t]{2}{*}{$\begin{array}{c}0 \\
\text { (days) }\end{array}$} & 20 & 60 & 180 & 540 & 1620 & 20 & 60 & 180 & 540 & 1620 \\
\hline & & \multicolumn{5}{|c|}{ A. $0.7 \mathrm{R} / \mathrm{day}$} & \multicolumn{5}{|c|}{ B. $2.1 \mathrm{R} / \mathrm{day}$} \\
\hline Newborn & 740 & 750 & 749 & $885^{\circ}$ & $\ldots$ & - & $\ldots$ & - & - & - & - \\
\hline 2 months & 662 & $830^{*}$ & $850^{\circ}$ & $867^{*}$ & $\ldots$ & -- & $779 *$ & $800^{4}$ & $885 *$ & 8es" & - \\
\hline 6 months & 888 & 897 & 902 & 876 & -- & -- & 901 & 884 & 892 & 883 & - \\
\hline \multirow[t]{2}{*}{15 months } & 869 & 931 & 893 & $\mathbf{8 B 1}$ & -- & $\cdots$ & 895 & 923 & 888 & - & - \\
\hline & & \multicolumn{5}{|c|}{ C. $6.3 \mathrm{R} / \mathrm{day}$} & \multicolumn{5}{|c|}{ D. $18.9 \mathrm{R} / \mathrm{day}$} \\
\hline Newborn & 740 & 818 & 807 & 821 & 784 & 749 & $\ldots$ & - & $-\ldots$ & $\ldots$ & $\bar{m}$ \\
\hline 2 months & 662 & 636 & $858^{*}$ & $823^{*}$ & 773 & $864^{*}$ & $818^{*}$ & $867^{*}$ & $867^{*}$ & $837^{*}$ & 740 \\
\hline 6 months & 888 & $965^{*}$ & 876 & 880 & 906 & 857 & 864 & 832 & 881 & 892 & 826 \\
\hline \multirow[t]{2}{*}{15 months } & 869 & 935* & 885 & 862 & 861 & -- & 919 & 892 & 896 & 919 & 845 \\
\hline & & \multicolumn{5}{|c|}{ E. $56.7 \mathrm{R} / \mathrm{day}$} & \multicolumn{5}{|c|}{ F. $36000 \mathrm{R} / \mathrm{du} y$} \\
\hline Newborn & 740 & $892^{4}$ & 807 & $77 i$ & 702 & --- & $\overline{709}$ & - & -- & $\ldots$ & $\overline{--}$ \\
\hline 2 months & 662 & 757 & 780 & $906^{*}$ & $817^{*}$ & 551 & 799 & 767 & $838^{*}$ & 666 & - \\
\hline 6 months & 888 & 931 & 884 & 844 & 870 & $792^{*}$ & $789 *$ & 847 & 821 & 827 & - \\
\hline 15 months & 869 & 921 & 861 & 863 & 903 & 872 & 848 & 838 & 840 & 852 & - \\
\hline
\end{tabular}

49 malignant tumors were diagnosed in experimental groups. Tumors were not predominantly of any single organ system and followed the rather generalized pattern normally associated with aging. This was true for both control and experimental groups.

\section{DISCUSSION}

The two replications were pooled in the above analysis despite the fact that the log-rank test sometimes claims significant differences between replications for a particular treatment combination. To see whether replication differences would affect the conclusions, we ran the log-rank tests for each replication separately for the 2- and 6-month groups for 20,60, and $180 \mathrm{rad}$. In each of the 12 cases, with one minor exception, the conclusions were exactly the same as those for the pooled data. In Sec. III we discussed censoring deaths from other causes. The early deaths occurred almost entirely within the first replication and accentunted the difference of the $2-$ month/20-rad/6.3-R/day group [Table IIIA and Fig. 2(b)]. Although we do not under- stand the causes of the differences between replications, pooling them seemed the feasible course.

We wish to qualify the conclusions somewhat for the following reasons: (1) the log-rank test is the state of the art in statistics, but its small sample properties are still under study; (2) we have conducted a large number of tests at the same significance level and $5 \%$ of theace we expect to be significant by chance alone. Nevertheless, the conclusions seem clear. The mice in our study were certainly not adversely affected by radiation doses of up to $180 \mathrm{rad}$ at rates of up to $56.7 \mathrm{R} / \mathrm{day}$, and it may be that their life spans increased as a result of the treatments.

We must also consider the difference in treatment between control mice and those being irradiated. As discussed in Sec. II, the control animals never spent time in the exposure rooms; they were joined by experimental mice after the desired total dowe had been attrined. There is certainly cause to suspect the control data at the axe of 2 months, from the early deaths apparent in the figures. To emphasize the possible importance of these carty deaths, the modian biftimes for 25,50 , and $75 \%$ of each group are given for comparison in Table $V$. We repeat 
TABLE V. Median Lifetime in Days from Birth versus Radiation Dose Rate and Age at Exposure as a Function of Total Dose. Median Lifetimes are for 25, 50, and 75\% of the Deaths in Each Group ${ }^{\mathrm{B}}$

\begin{tabular}{|c|c|c|c|c|c|c|c|c|c|c|c|c|}
\hline \multirow{2}{*}{$\begin{array}{l}\text { Age at } \\
\text { Exposure }\end{array}$} & \multirow[b]{2}{*}{$\%$} & \multirow{2}{*}{$\begin{array}{c}0 \\
\text { (days) }\end{array}$} & \multicolumn{10}{|c|}{ Total Dose (rad) } \\
\hline & & & 20 & 60 & 180 & 540 & 1620 & 20 & 60 & 180 & 540 & 1620 \\
\hline & & & \multicolumn{5}{|c|}{ A. $0.7 \mathrm{R} / \mathrm{day}$} & \multicolumn{5}{|c|}{ B. $2.1 \mathrm{R} / \mathrm{d} x \mathrm{y}$} \\
\hline \multirow[t]{3}{*}{ Newborn } & 25 & 536 & 687 & 637 & 859 & $\ldots$ & $\overline{-}$ & $\overline{--}$ & $\ldots$ & $\ldots$ & $\ldots$ & 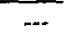 \\
\hline & so & 767 & 830 & 778 & $936^{*}$ & -- & -- & -.- & -- & $\cdots$ & -- & - \\
\hline & 75 & 928 & 865 & 881 & 988 & -- & --. & --- & -- &.- &.-- & -.. \\
\hline \multirow[t]{3}{*}{2 months } & 25 & 352 & 750 & 779 & 736 & - & $\ldots$ & 675 & 720 & 772 & 824 & -- \\
\hline & 50 & 757 & $886^{*}$ & $883^{*}$ & $892^{*}$ & -- & -- & $903^{*}$ & $861^{\circ}$ & $940^{\circ}$ & $967^{*}$ & - \\
\hline & 75 & 886 & 983 & 947 & 992 & -- & -- & 979 & 948 & 1023 & 1028 & $\ldots$ \\
\hline \multirow[t]{3}{*}{6 months } & 25 & 830 & 825 & 839 & 806 &.-- & --- & 855 & 823 & 854 & 763 & -- \\
\hline & 50 & 917 & 930 & 941 & 919 & $\cdots$ & -- & 947 & 923 & 920 & 933 & -- \\
\hline & 75 & 987 & 998 & 981 & 968 & $-\cdots$ & $\ldots$ & 1019 & 975 & 1001 & 998 & -- \\
\hline \multirow[t]{4}{*}{15 months } & 25 & 756 & 856 & 833 & 807 & $\cdots$ & -- & 792 & 860 & 841 & -- & $\ldots$ \\
\hline & so & 892 & $964^{*}$ & 904 & 885 & $\cdots$ & $\ldots$ & 925 & 925 & 924 & $\ldots$ & --- \\
\hline & 75 & 960 & 1032 & 985 & 950 & $\cdots$ & $\cdots$ & 1007 & 1020 & 992 & $\cdots$ & $\cdots$ \\
\hline & & & \multicolumn{5}{|c|}{ C. $6.3 \mathrm{R} / \mathrm{dny}$} & \multicolumn{5}{|c|}{ D. $18.9 \mathrm{R} / \mathrm{day}$} \\
\hline \multirow[t]{3}{*}{ Newborn } & 25 & 536 & 765 & 696 & 699 & 645 & 662 &.-- & -- & $\ldots$ & $\ldots$ & $\cdots$ \\
\hline & 50 & 767 & 805 & 889 & $892^{*}$ & 868 & 779 & -- & $-\ldots$ & -- & -- & $\ldots$ \\
\hline & 75 & 928 & 915 & 920 & 982 & 930 & 802 & -.. & -- & - & - & $\cdots$ \\
\hline \multirow[t]{3}{*}{2 months } & 25 & 352 & 326 & 761 & 751 & 625 & 801 & 674 & 794 & 774 & 774 & 606 \\
\hline & 50 & 757 & $598 *$ & 879* & $868^{*}$ & $839^{*}$ & $883^{*}$ & $889^{*}$ & $904^{*}$ & $877^{\star}$ & $877^{\star}$ & 769 \\
\hline & 75 & 886 & 959 & 970 & 937 & 961 & 978 & 976 & 988 & 962 & 950 & 901 \\
\hline \multirow[t]{3}{*}{6 months } & 25 & 830 & 899 & 821 & 806 & 815 & 771 & 795 & 730 & 852 & 813 & 751 \\
\hline & 50 & 917 & $996^{\circ}$ & 919 & 899 & 931 & 918 & 911 & 861 & 934 & 925 & 857 \\
\hline & 75 & 987 & 1084 & 1010 & 1004 & 1021 & 979 & 1023 & 961 & 989 & 1003 & 960 \\
\hline \multirow[t]{3}{*}{15 months } & 25 & 756 & 863 & 805 & 754 & 754 & - & 823 & 757 & 819 & 833 & 788 \\
\hline & 50 & 892 & $936^{*}$ & 907 & 867 & 872 & - & 925 & 937 & 929 & 929 & 878 \\
\hline & 75 & 960 & 1049 & 995 & 1001 & 990 & - & 1040 & 987 & 990 & 1016 & 946 \\
\hline
\end{tabular}

\begin{tabular}{|c|c|c|c|c|c|c|c|c|c|c|c|c|}
\hline \multirow[b]{2}{*}{ Newborn } & \multirow[b]{2}{*}{25} & \multirow[b]{2}{*}{536} & \multicolumn{5}{|c|}{ E. $56.7 \mathrm{R} / \mathrm{day}$} & \multicolumn{5}{|c|}{ F. $36000 \mathrm{R} / \mathrm{day}$} \\
\hline & & & 871 & 605 & 570 & 520 & -- & 667 & -- & - & - & $\cdots$ \\
\hline & 50 & 767 & $931^{*}$ & 888 & 870 & 769 & $\cdots$ & 753 & -- & - & - & - \\
\hline & 75 & 928 & 980 & 968 & 964 & 902 & - & 775 & - & - & -- & $\cdots$ \\
\hline \multirow[t]{3}{*}{2 months } & 25 & 352 & 693 & 641 & 84 & 696 & 257 & 698 & 688 & 748 & 463 & - \\
\hline & so & 757 & $845^{*}$ & $896^{\circ}$ & $952^{*}$ & $847^{\circ}$ & $588^{*}$ & $881^{*}$ & $838^{\circ}$ & $856^{*}$ & 754 & - \\
\hline & 75 & 886 & 899 & 971 & 1005 & 938 & 875 & 1013 & 968 & 970 & 894 & - \\
\hline \multirow[t]{3}{*}{6 months } & 25 & 830 & 898 & 808 & 811 & 795 & 643 & 662 & 766 & 712 & 743 & - \\
\hline & $\mathbf{s 0}$ & 917 & 981* & 917 & 902 & 904 & 898 & 855 & 894 & 835 & 814 & - \\
\hline & 75 & 987 & 1038 & 975 & 971 & 996 & 950 & 961 & 1004 & 955 & 967 & - \\
\hline \multirow[t]{3}{*}{15 months } & 25 & 756 & 865 & 782 & 770 & 801 & 773 & 724 & 742 & 722 & 754 & -- \\
\hline & 50 & 892 & 918 & 872 & 835 & 927 & 885 & 838 & 796 & 845 & 829 & - \\
\hline & 75 & 960 & 1047 & 946 & 971 & 1027 & 972 & 970 & 928 & 916 & 982 & -- \\
\hline
\end{tabular}

The * indicates simificant difierence from controla at the $5 \%$ level.

The -- indicates no enimals were placed in these groupe. 
the $50 \%$ points from Table III, for comparison with the other fractional life span data. The differences in the 2month-old groups become obvious in considering the early-death patterns $(25 \%)$ in the controls. The same pattern emerges in the 2-month age group with a 20-rad dose at $6.3 \mathrm{R} /$ day and with a 1620 -rad dose at 56.7 $\mathrm{R} /$ day. Early-death patterns in the controls doubtless are responsible for most of the calculated significant differences noted by the asterisks in Table $V$.

We can offer another interpretation of the same control data. The life span for 6-month controls, for example, is conditioned on their having survived 6 months. Deaths occurring before 6 months are not part of their average life span. As a partial adjustment we can put the controls on a 15-month (450-day) basis. In Fig. 3(a)-(c), we plotted the cumulative proportion of mice surviving in control groups after deleting deaths occurring to 450 days. Fig. 3(c) shows that control life span differences are minimized by this procedure, but the 6 month-old group still significantly outlived other agegroup controls. When we remove early deaths (300-400 days) from all control and experimental groups, we eliminate several of the significant differences, but the median life spans of irradiated animals are as long or longer than are those of controls for 180-rad doses or less at rates of up to $56.7 \mathrm{R} /$ day.

Storer et ai. ${ }^{3}$ present life-shortening data for strain RFM mice (female and male) given external whole-body gamma-ray exposures of doses ranging from 0 to 400 $\mathrm{rad}$ at $45 \mathrm{R} /$ minute. Although female mice given $10 \mathrm{rad}$ showed no significant life shortening, with doses of 25 rad and above life-shortening effects were observed. Male mice showed significant life shortening only when given doses of $50 \mathrm{rad}$ or more, and mean life span was lengthened at a total dose of $10 \mathrm{rad}$. At a lower rate ( 8.3 $\mathrm{R} /$ day) life shortening was reported at $50 \mathrm{rad}$ and greater doses, but the life-shortening slope was below that of the higher rate. These data are not inconsistent with data from our earlier study with this same strain of mice in which we gave 12 relatively high dose/dose-rate combinations. ${ }^{10}$ The results of Storer et al. ${ }^{3}$ also are not inconsistent with the data obtained from the present study when we consider the mouse strain, dose, exposure-rate, exposure-age, and condition differences between experiments.

Some irradiation studies of human populations may help us evaluate our own study. Research in life shortening from nonspecific causes among 82000 Japanese ABomb survivors is ongoing. Any life shortening that has been observed is attributed to carcinogenic effects
(Beebe, Vol. II, pp. 3-27,; ${ }^{2}$ however, the dose and dose rates that seemed to increase the incidence of leukemia are quite high. In a well-controlled study on low-dose radiation and leukemia, Linos et al. ${ }^{21}$ have reported that low levels of external exposure to medical radiation probably did not increase the risk of leukemia. Individuals exposed to plutonium between 1944 and 1945, and others with potential exposures since that period, have shown no increase in death rates due to any malignant or nonmalignant disease (Voelz et al., Vol. II, pp. 353-367). ${ }^{2}$

The relatively few benign and malignant tumors that we observed in our study did not appear to be influenced by dose, exposure rate, or age at exposure. When the number of benign and malignant tumors was expressed as a percentage of the number of mice observed, control mice had fewer than 0.03 benign and 0.05 malignant tumors; treated mice, fewer than 0.01 benign and 0.02 malignant tumors. For each age group, we determined the mean age at death for control and treated mice with grossly obvious tumors, and we found no significant influence on the median life spans reported in the tables.

The results of our study are in general agreement with the results of other researchers in human and animal life span irradiation studies. The largest discrepancy occurs in the abundant lengthening of life spans we saw in younger animals at most dose rates, not allowing an extrapolation to zero dose. Storer et al. ${ }^{3}$ used a linear extrapolation for the dose/life-shortening relationships in RFM male mice with doses ranging from at least 0 to 50 rad. This linear relationship at low doses and dose rates was also reprited by Sacher and Grahn.22 The linearquadratic relationship between life shortening and dose obviously will fit these circumstances because the squared term does not dominate until higher doses are reached. ${ }^{23}$ Our data obtained over widely ranging dose, exposure-rate, and exposure-age conditons fail to consistently support any mathematical function that may predict radiation-induced life shortening from radiation exposures approaching background levels. In fact, our data suggest beneficial effects from low-dose and lowdose-rate gamma-ray exposure.

Radiation-induced hormesis in vertebrates appeared in the literature in the early 1900 . $^{*}$ Low-level external irradiation was shown to increase resintance to various infections and to favorably alter physiological function. Luckey's monograph" tabulates specific inatances and three recent publications ${ }^{20-26}$ discuss low-level iosizing radiation as a stimulating agent. Luckey reports the results of Lorenz et $\mathrm{al}^{27}$ in which $\gamma$-dowe rates of 0.11 , 
1.1 , and $2.2 \mathrm{R} /$ day resulted in some instances in increased life spans over the controls (mice, guinea pigs, and rabbits).

The BEIR report ${ }^{28}$ deals with life shortening in terms of cancer induction, and a recent NCRP Publication ${ }^{23}$ states that "studies on the effects on life span contribute appreciably to quantitative knowledge on the influence of dose-rate on tumorigenesis." This reasonable approach recognizes the uncertainties in life shortening at nearbackground levels. Because the research data are insufficient to statistically separate the life spans of experimental subjects from those of controls, to use cancer risk in terms of prorated individual exposures (man-rems) is logical. This is appealing because it enables establishment of exposure guidelines based upon cancer risk without using terms of life shortening.

In conclusion, our data and earlier studies suggest that life shortening from exposure to ionizing radiation is not a feasible endpoint on which to base any harmful biological effects that may result at very low doses and dose rates. The lengthening of some of the mean life spans observed in this study indicates the possible existence of a threshold dose for the onset of measurable life span shortening. Cancer incidence, however, may not be directly related to population life span at these dosage levels. From the many total dose, dose-rate, and exposure-age combinations that compose our data, we conclude that life spans among irradiated groups were not shortened compared with life spans of corresponding control mice. We suggest that these dosage regions be considered important in selecting external radiation parameters that avoid obvious deleterious effects, including life-shortening cancer.

\section{ACKNOWLEDGMENTS}

We are grateful to J. R. Prine and his staff for postmortem necropsies, histological preparations, and pathology reports. We are also grateful to $O$. S. Johnson and R. F. Archuleta for essential technical support. We are indebted to G. L. Voelz for making it possible to collate and document the data of this 4-year study. G. L. Voelz, J. W. Healy, J. R. Prine, and R. A. Walters reviewed the manuscript and their contributions to the final product are appreciated.

\section{REFERENCES}

1. L. H. Strong, "The Life Span Shortening Effects of Irradiation: An Investigation of the Interrelation of Premature Death After Irradiation, Death Under Long-Protracted Irradiation and the Reduced Acute Lethal Dose in Old Age," Ph.D. Thesis, Department of Radiation Biology and Biophysics, University of Rochester, Rochester, New York, 1965.

2. "Late Biological Effects of Ionizing Radiation," Proc. IAEA Symp., Vienna, Austria, March 13-17. 1978, Vols. I and II (1978).

3. J. B. Storer, L. J. Serrano, E. B. Darden, Jr., M. C Jernigan, and R. L. Ulbrick, "Lire Shortening in RFM and BALB/C Mice as a Function of Radiation Quality, Dose, and Dose Rate," Radiat. Res. 78, 122-161 (1979).

4. "Hormesis with lonizing Radiation," T. D. Luckey, Ed. (CRC Press, Inc., Boca Raton, Florida, 1981).

5. J. M. Yuhas, "Genetic Control of Aging and Radiation-Induced Life Shortening in Mice." Jackson Laboratory report NYO-3314-15 (October 1969).

6. J. B. Storer, "Radiation Resistance With Age in Normal and Irradiated Populations of Mice," Radiat. Res. 25, 435-459 (1965).

7. A. C. Upton, M. L. Randolph, and J. W. Conkiin, "Late Effects of Fast Neutrons and Gamma Rays in Mice as Influenced by the Dose Rate of Irradiation: Life Shortening," Radiat. Res. 32, 493-509 (1967).

8. J. B. Storer, "Evaluation of Radiation Response as an Index of Aging in Mice," Radiat. Res. 17, 878-902 (1962).

9. J. F. Spalding, R. F. Archuleta, and J. R. Prine, "Delayed Radiation Injury of Gut-Exposed and Gut-Shielded Mice. II. The Decrement in Life Span," Los Alamos Scientific Laboratory report LA-6717-MS (January 1978). 
10. J. F. Spalding, O. S. Johnson, and P. C. McWilliams, "Dose Rate - Total Dose Effect from Single Short-Duration Gamma-Ray Exposure on Survival Time in Mice," Radiat. Res. 32, 21-26 (1967).

11. G. W. Casarett, "Similarities and Contrasts between Radiation and Time Pathology," Adv. Gerontol. Res. 1, 109-63(1964).

12. P. J. Lindop and J. Rotblat, "Shortening of Life and Causes of Death in Mice Exposed to a Single Whole-Body Dose of Radiation," Nature 189, 645-48 (1961).

13. P. J. Lindop and J. Rotblat, "Dependence of Radiation-Induced Life-Shortening on Dose-Rate and Anesthetic," Proc. Symp. Basis Aetiology Late Somatic Eff. Ioniz. Radiat., UNESCO and IAEA, R. J. C. Harris, Ed. (Academic Press, London and New York, 1963), pp. 313-318.

14. P. Alexander and D. I. Connell, "Differences Between Radiation-Induced Life-Shortening in Mice and Normal Aging as Revealed by Serial Killing," Proc. Symp. Basis Aetiology Late Somatic Eff. Ioniz. Radiat., UNESCO and IAEA, R. J. C. Harris, Ed. (Academic Press, London and New York, 1963), pp. 277-283.

15. P. Alexander and D. I. Connell, "Shortening of the Life Span of Mice by Irradiation with X-rays and Treatment with Radiomimetic Chemicals," Radiat. Res. 12, 38-48 (1960).

16. R. H. Mole, "Does Radiation Age Produce NonSpecific Life-Shortening?" Proc. Symp. Basis Aetiology Late Somatic Eff. Ioniz. Radiat., UNESCO and IAEA, R. J. C. Harris, Ed. (Academic Press, London and New York, 1963), pp. 273-276.
17. G. Siline and P. Metalli, "Preliminary Results From a Split Dose Experiment on Late Effects of Ionizing Radiation in the Mouse. Data on Life Span Shortening," Radiat. Ageing, Proc. Coiloq., Semmering, Austria, June 23-24, 1966, P. J. Lindop and G. A. Sacher, Eds. (Taylor and Francis Ltd., Red Lion Court, London, 1966), pp. 207-215.

18. H. E. Walburg, Jr., G. E. Cosgrove, and A. C. Upton, "Longevity as Influenced by Irradiation in Germfree Mice," Radiat. Ageing, Proc. Collog., Semmering, Austria, June 23-24, 1966, P. J. Lindop and G. A. Sacher, Eds. (Taylor and Francis Ltd., Red Lion Court, London, 1966), pp. 361-365.

19. R. R. Kohn, "A Possible Final Common Pathway for Natural Aging and Radiation Induced LifeShortening," Radiat. Ageirg, Proc. Colloq., Semmering, Austria, June 23-24, 1966, P. J. Lindop and G. A. Sacher, Eds. (Taylor and Francis Ltd., Red Lion Court, London, 1966), pp. 373-391.

20. R. E. Anderson, J. V. Scaletti, and J. L. Howarth, "Radiation-Induced Life Shortening in Germfree Mice," Exp. Gerontol. 7, 289-301 (1972).

21. A. Linos, J. E. Gray, A. L. Orvis, R. A. Kyle, W. M. O'Fallon, and L. T. Kurland, "Low-Dose Radiation and Leukemia," New England J. Med. 302, 20, 1101-1105 (1980).

22. G. A. Sacher and D. Grahn, "Survival of Mice Under Duration-of-Life Exposure to Gamma Rays, I. The Dosage-Survival Relation and the Lethality Function," J. Nat. Cancer Inst. 32, 277 (1964).

23. "Influence of Dose and Its Distribution in Time on Dose-Response Reiationships for Low LET Radiations," National Council on Radiation Protection and Measurements report NCRP-64 (April 1980). 
24. T. D. Luckey, “Hormesis," Letter, Nucl. News 24, 15, 48-54 (1981).

25. R. J. Hickey, "Hormesis," Letter, Nucl. News 24, $15,54-55$ (1981).

26. R. J. Hickey, E. J. Bowers, and I. E. Allan, "TMI Psychological Impact," Nucl. News 25, 7, 28-31 (1982).

27. E. Lorenz, L. O. Jacobsen, W. E. Heston. M. Shimkin, A. B. Eschenbrenner, M. K. Donizer, and R. Schwersthal, "Effects of Long-Continued Total
Body Gamma Irradiation on Mice, Guinea Pigs, and Rabbits. III. Effects on Life Span, Weight, Bluod Picture and Carcinogenesis, and the Role of the Intensity of Radiation," in Biological Effects of External $X$ and Gamma Radiation, Part I, R. E. Zirkle, Ed. (McGraw-Hill, New York, 1954), p. 24.

28. "The Effects of Populations of Exposure to Low Levels of Ionizing Radiation," Committee on The Biological Effects of Ionizing Radiation, National Research Council, National Academy of Sciences, Washington, D. C. (1980). 


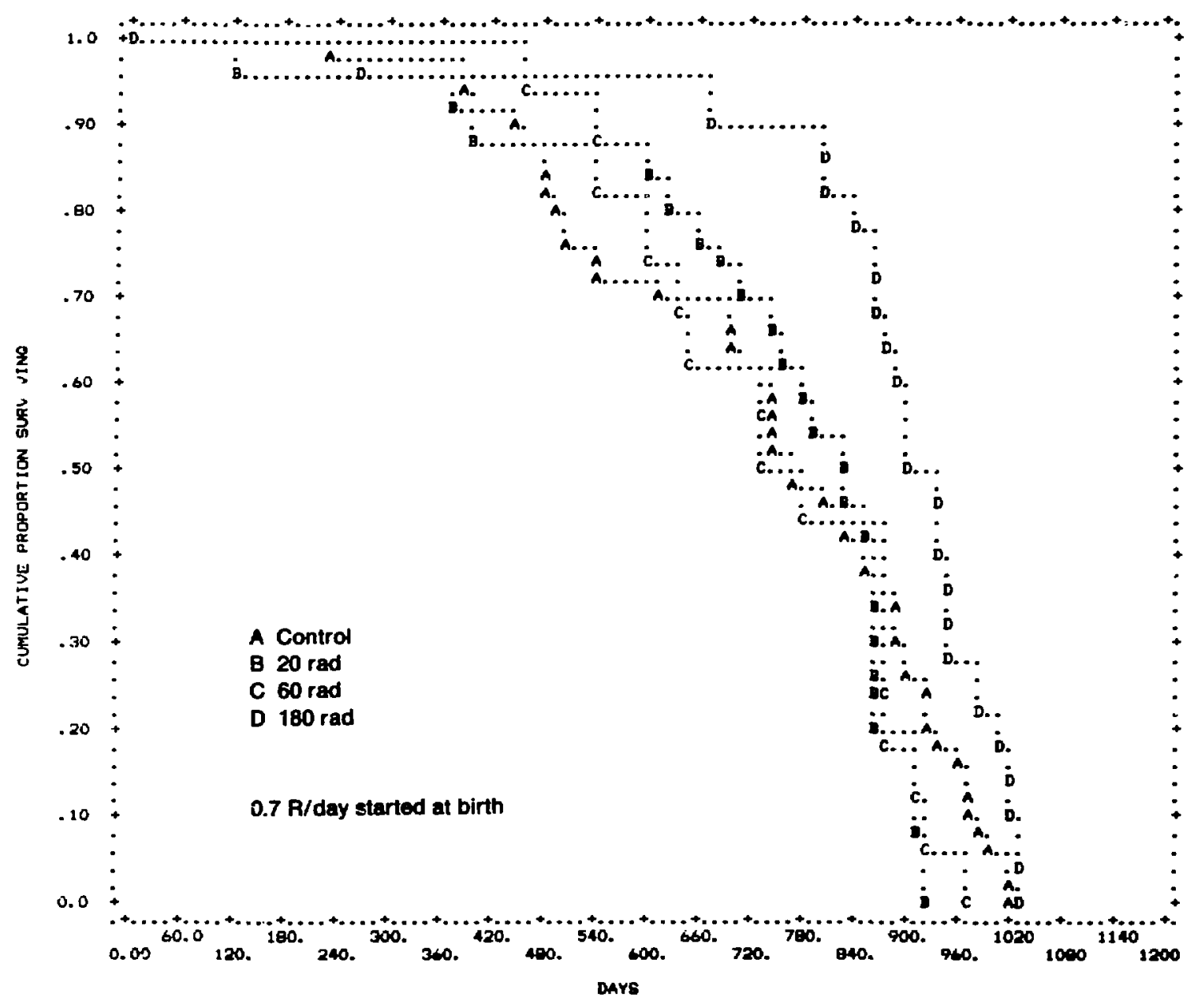

(a)

Fis. 1 (a)-(v). Cumulative proportion of mice surviving after specified dose rates of specific samma-ray dowes. 


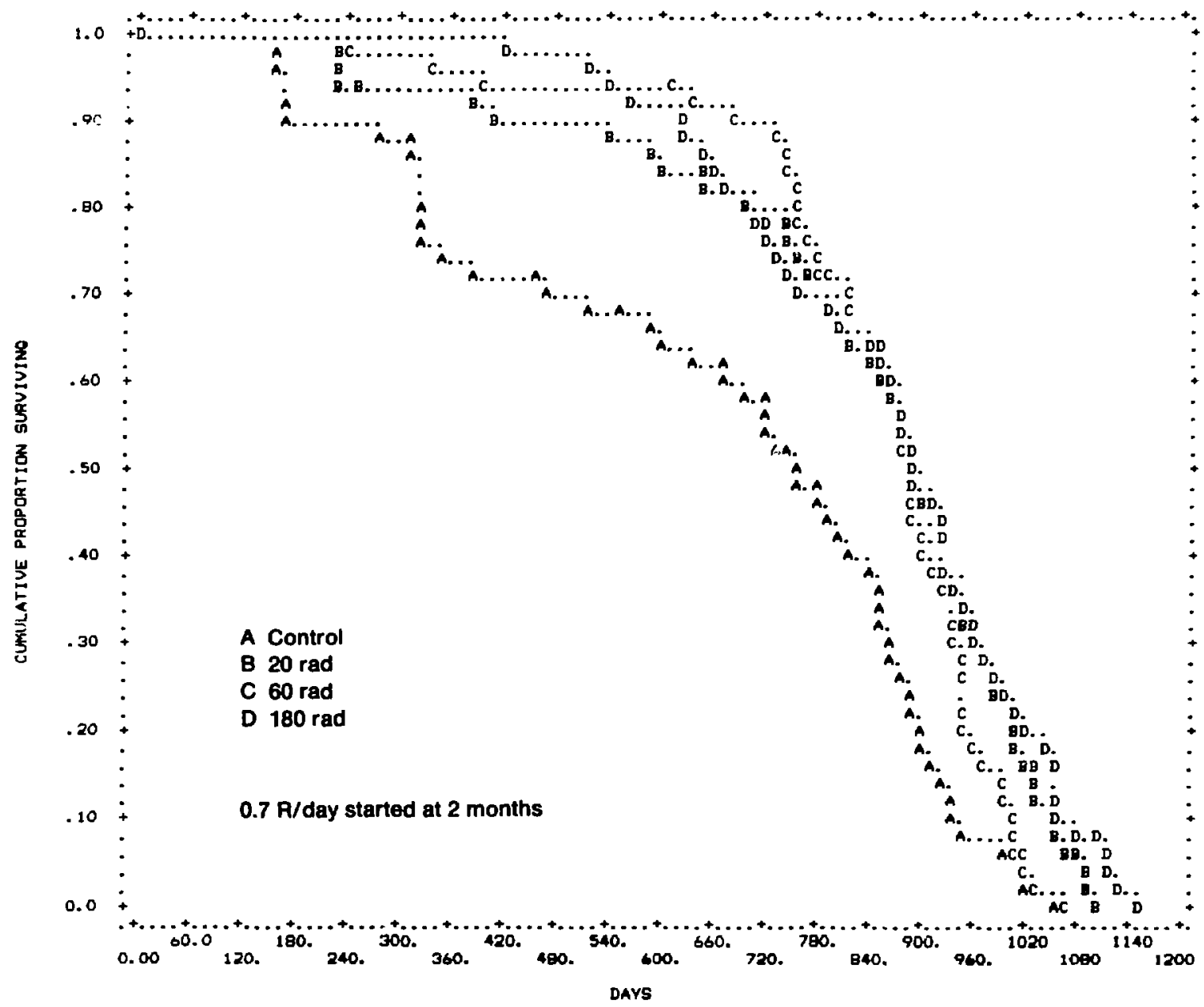

(b)

Fis. I. (cont)

13 


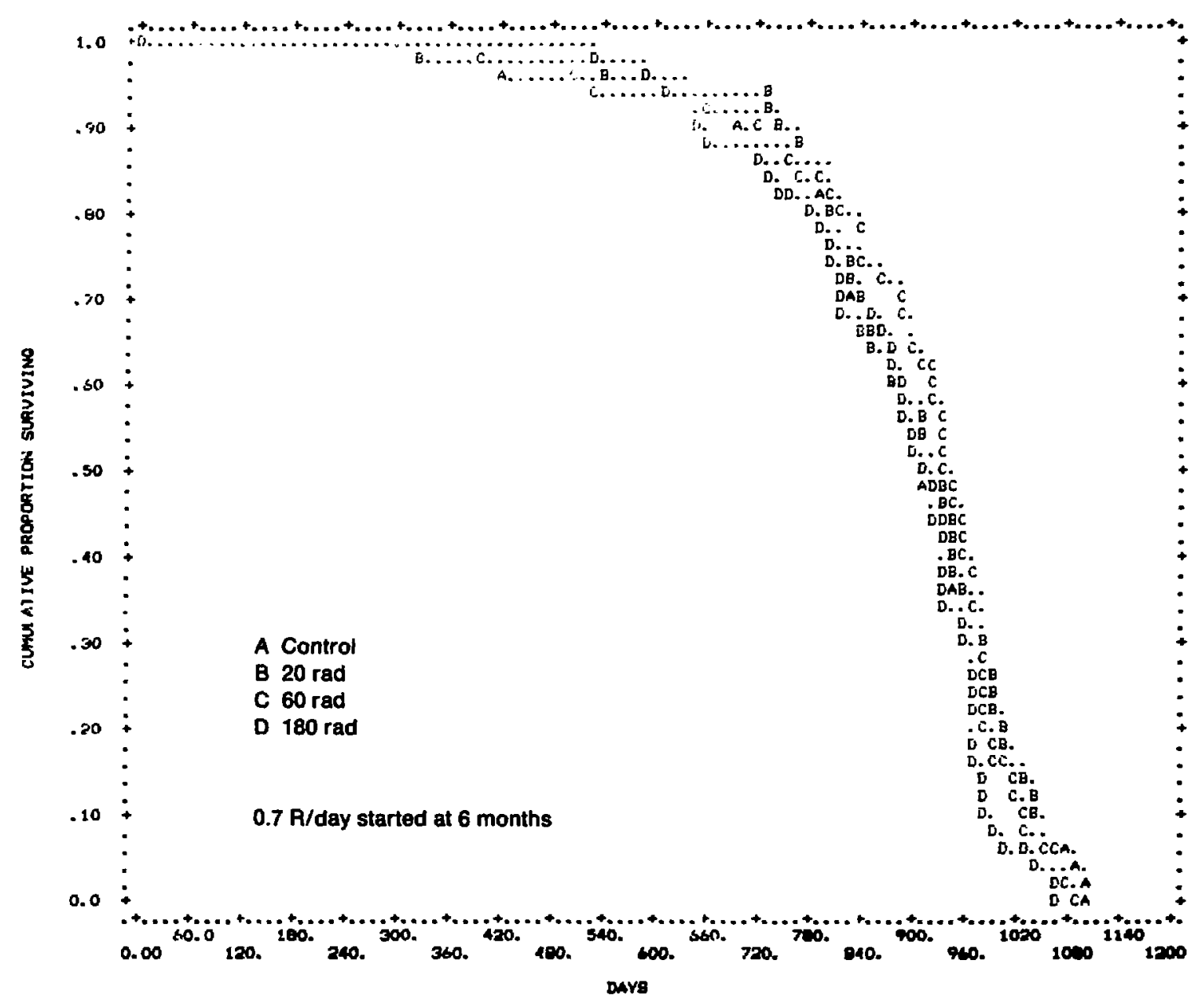

(c)

Fin. 1. (comt) 


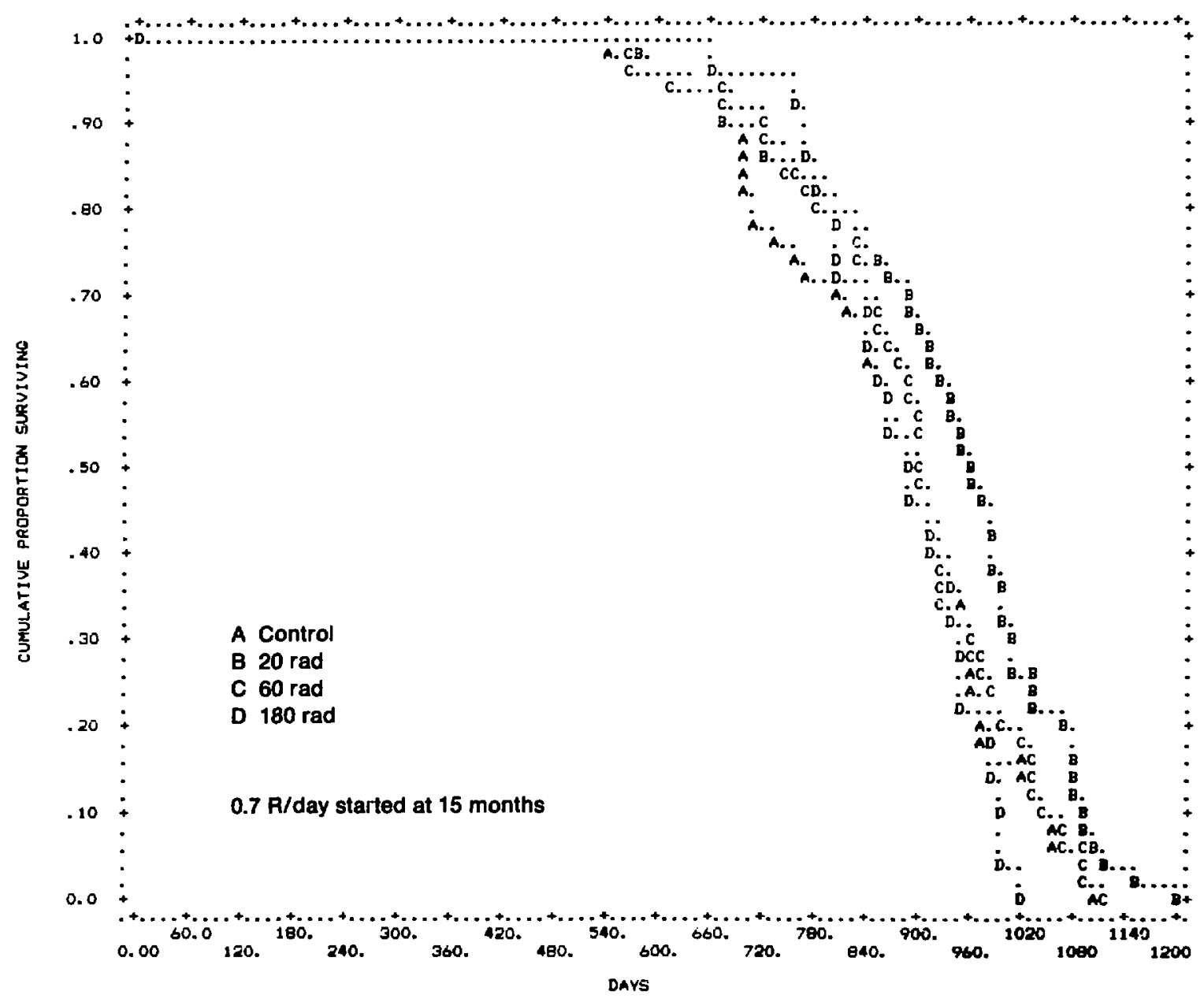

(d)

Fig. 1. (cont) 


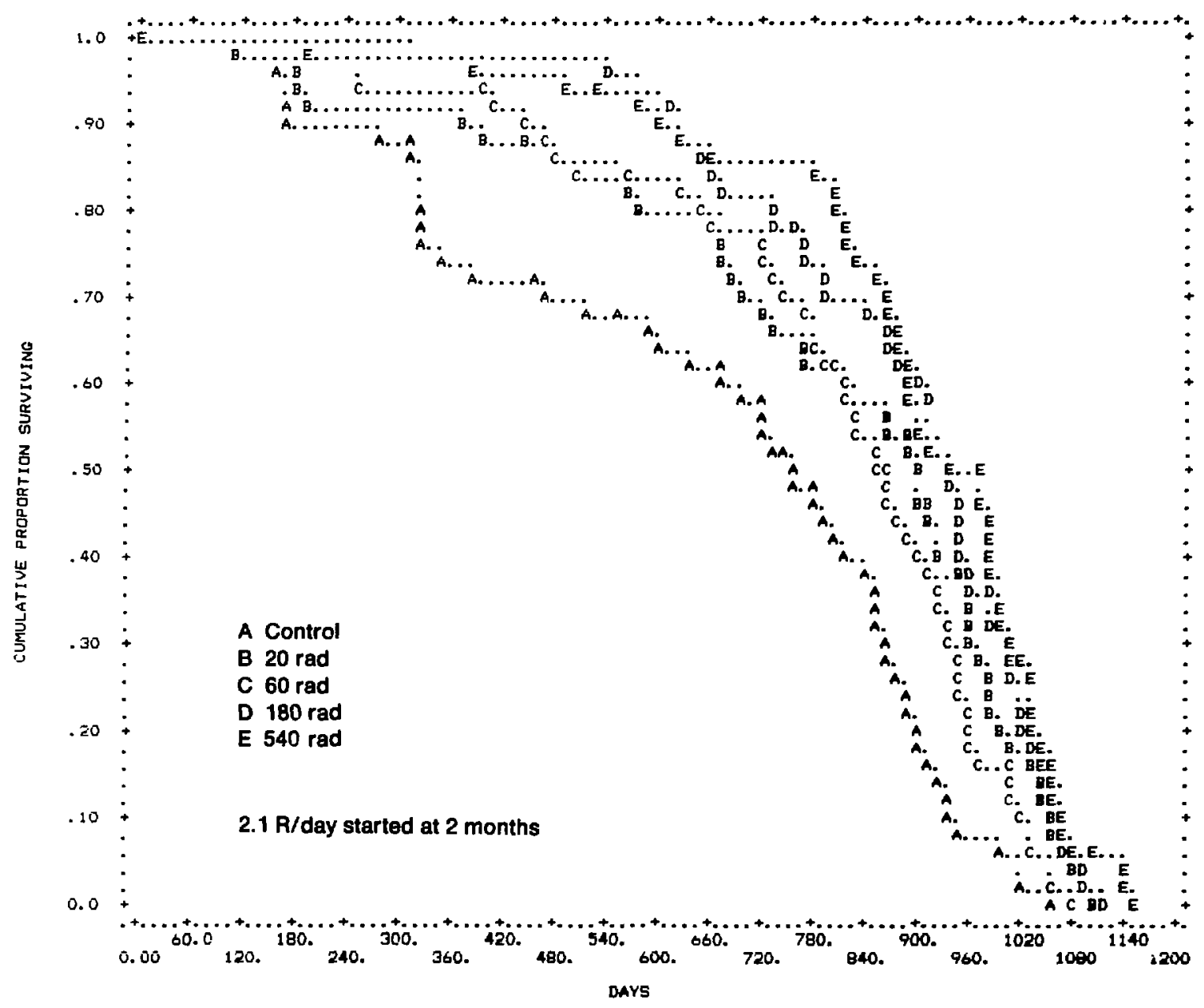

(e)

Fir. 1. (comt) 


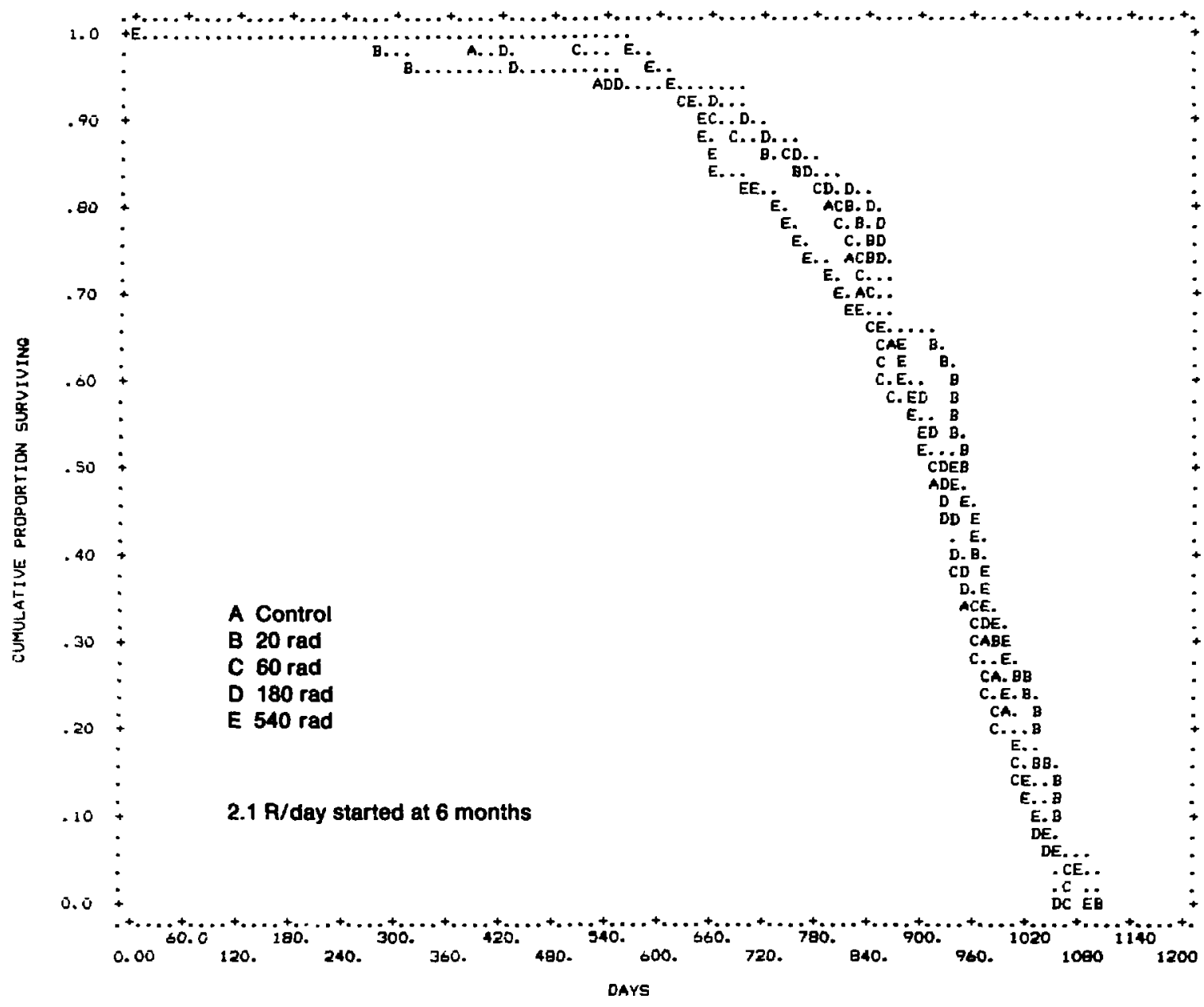

(f)

Fig. 1. (cont) 


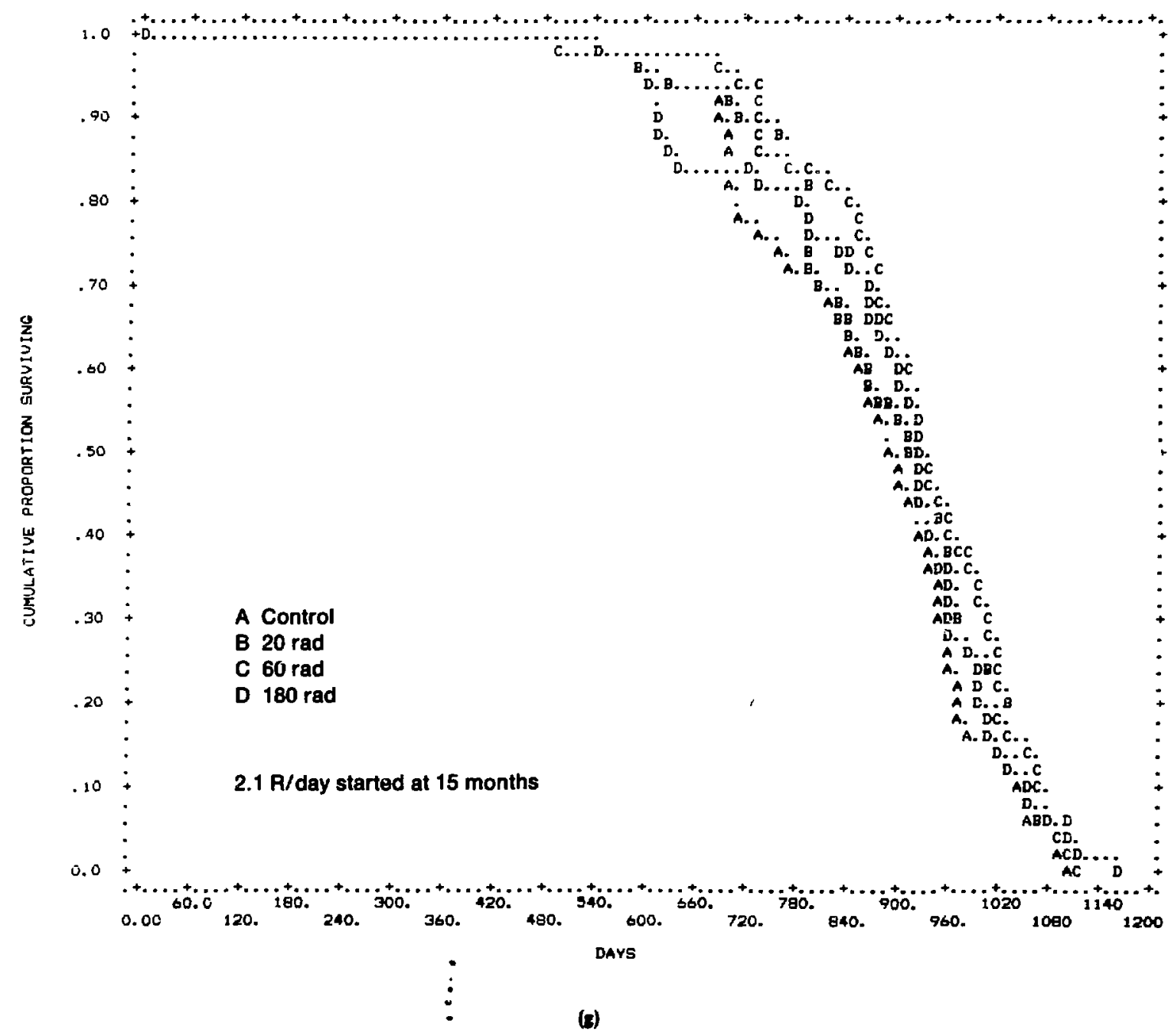

Fig. 1. (cont) 


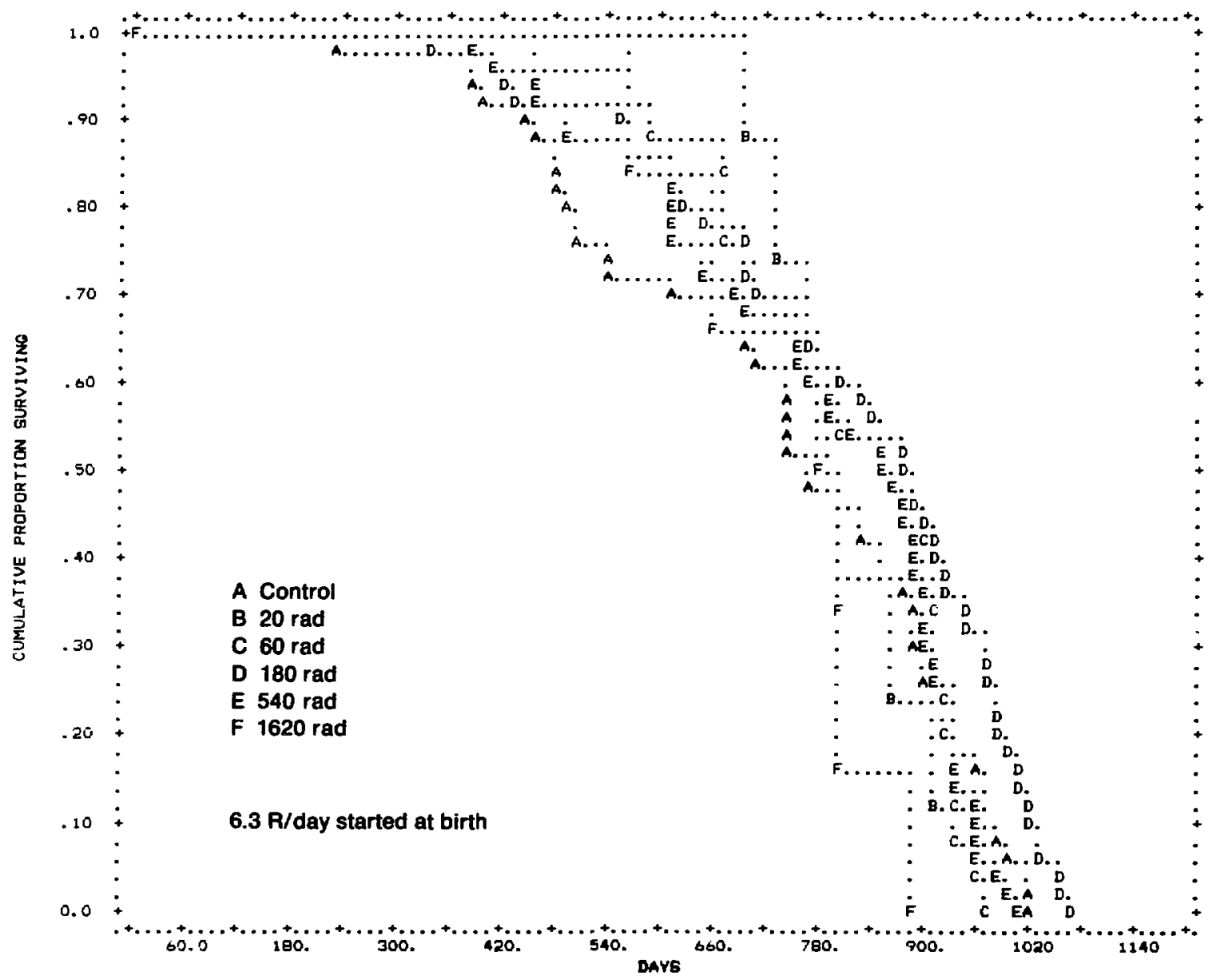

(h)

Fig. 1. (cont) 


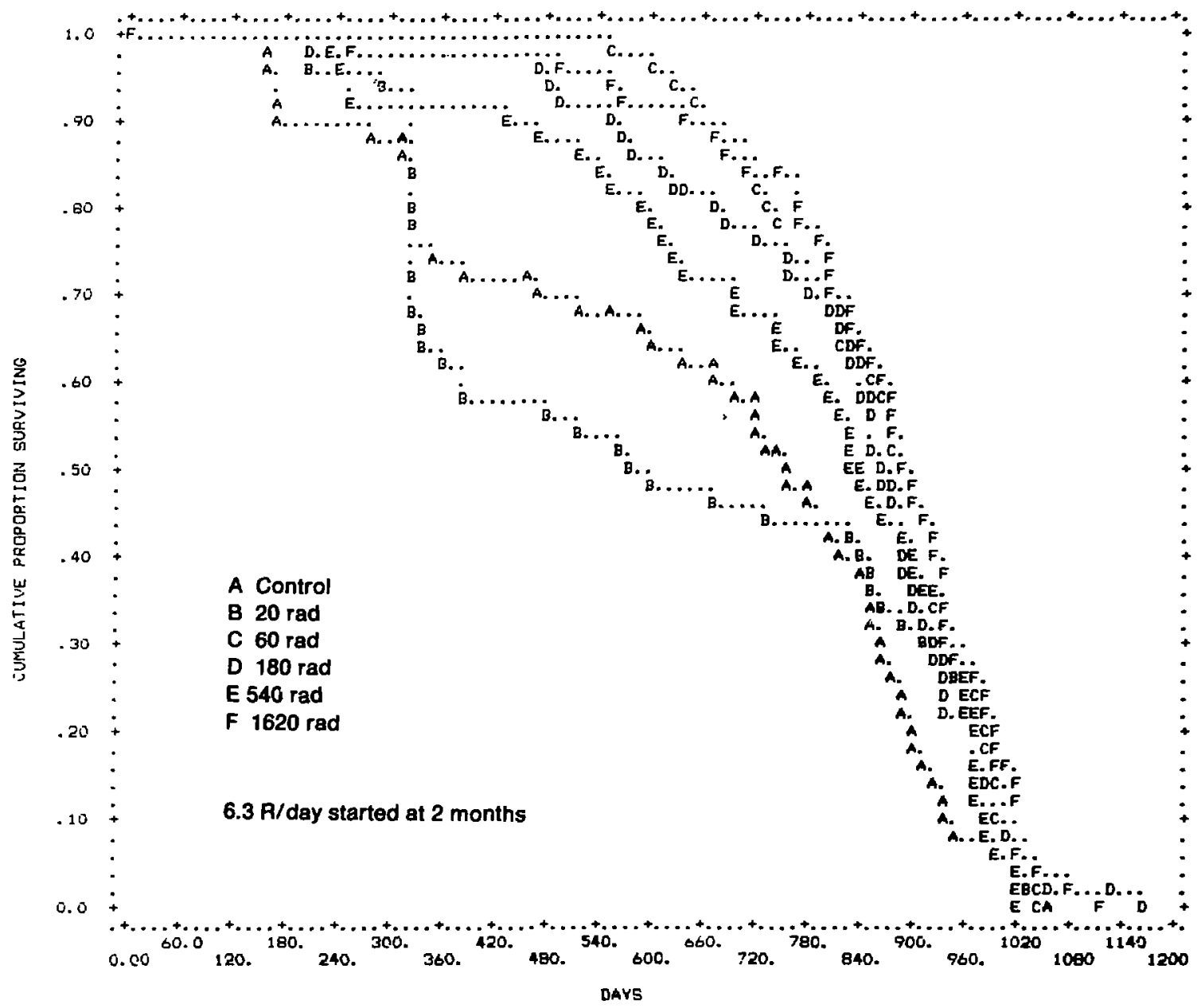

(i)

Fig. 1. (cont)

20 


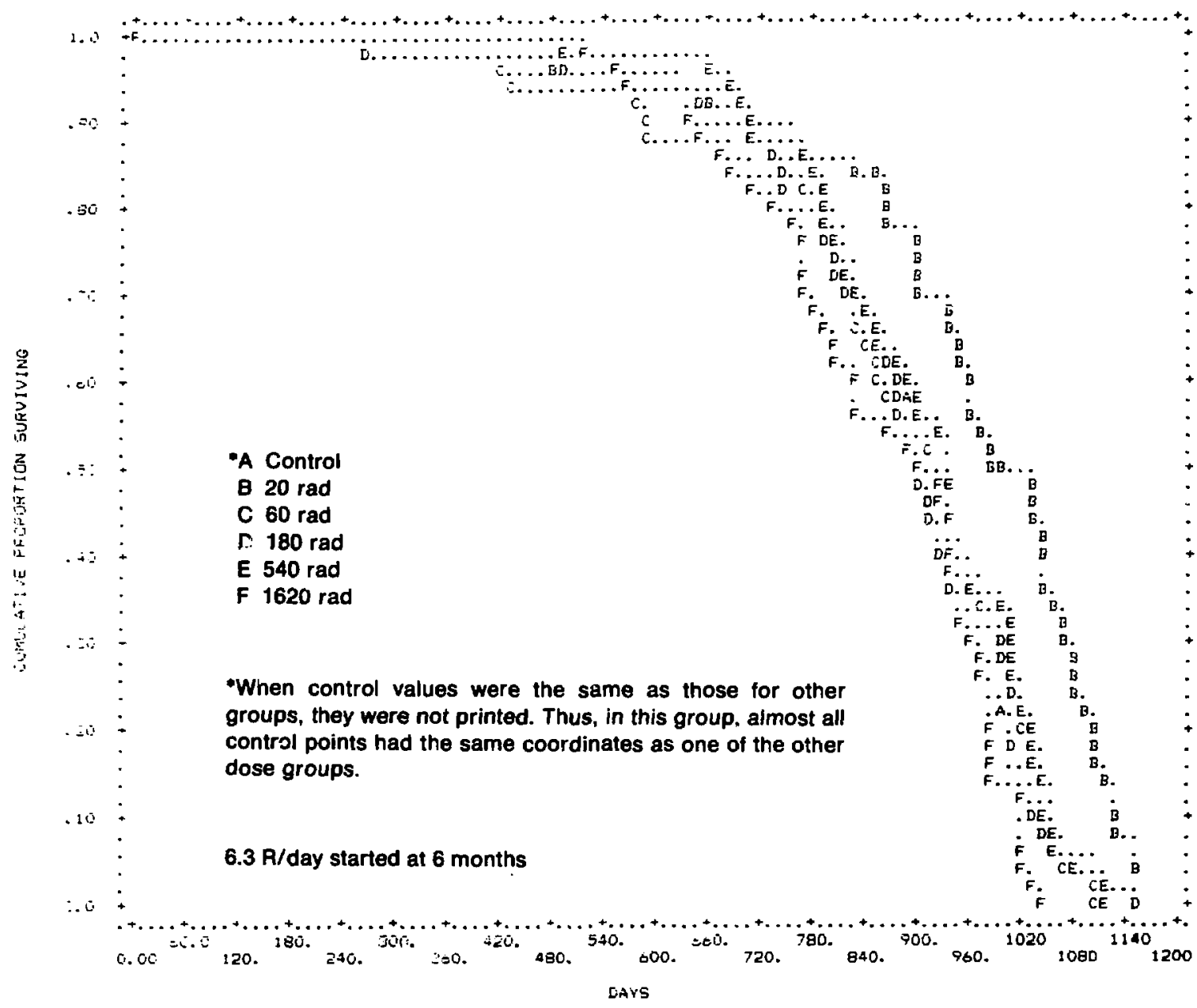

(j)

Fiz. 1. (cont) 


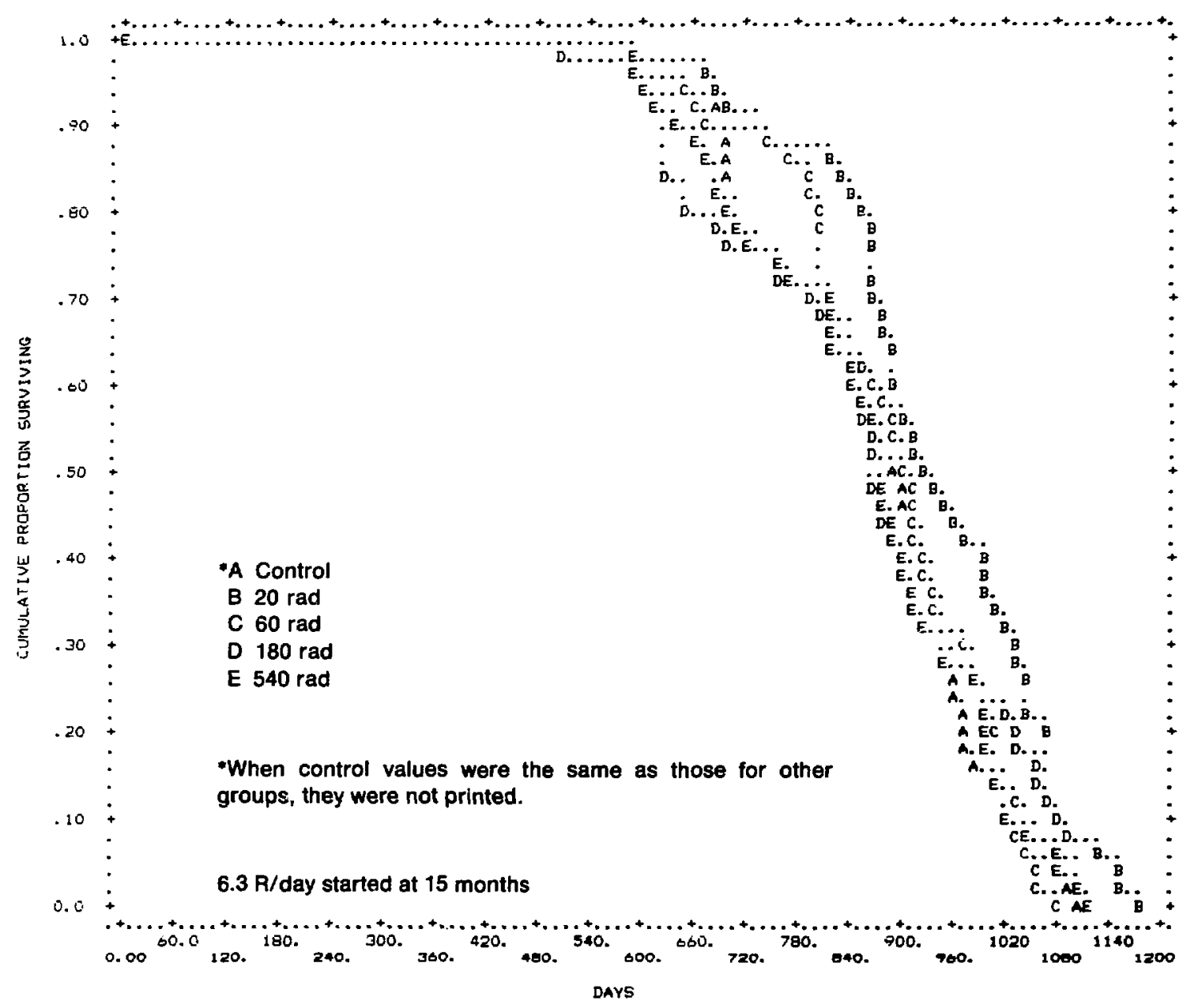

(k)

Fis. 1. (cont) 


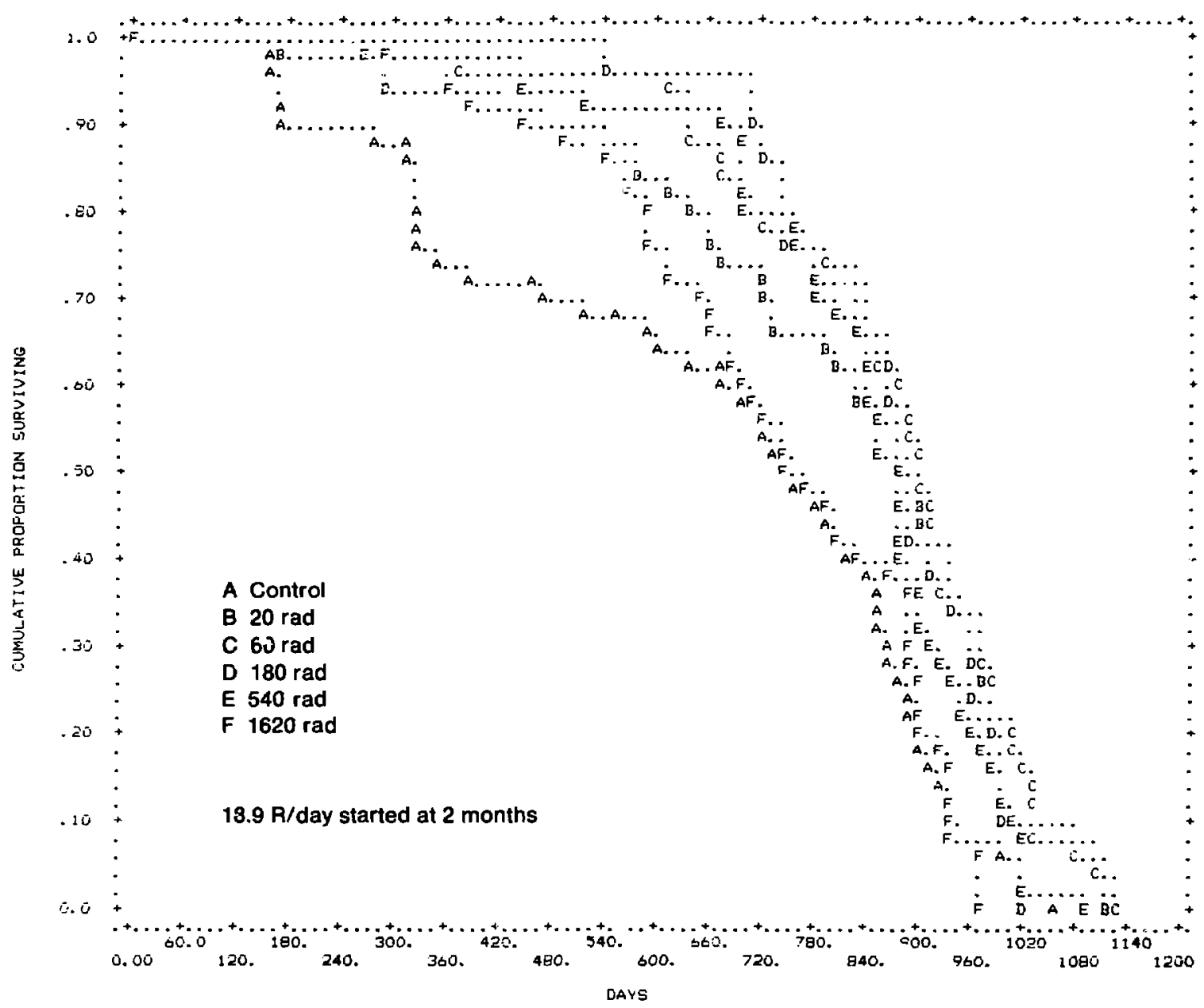

(I)

Fig. 1. (cont) 


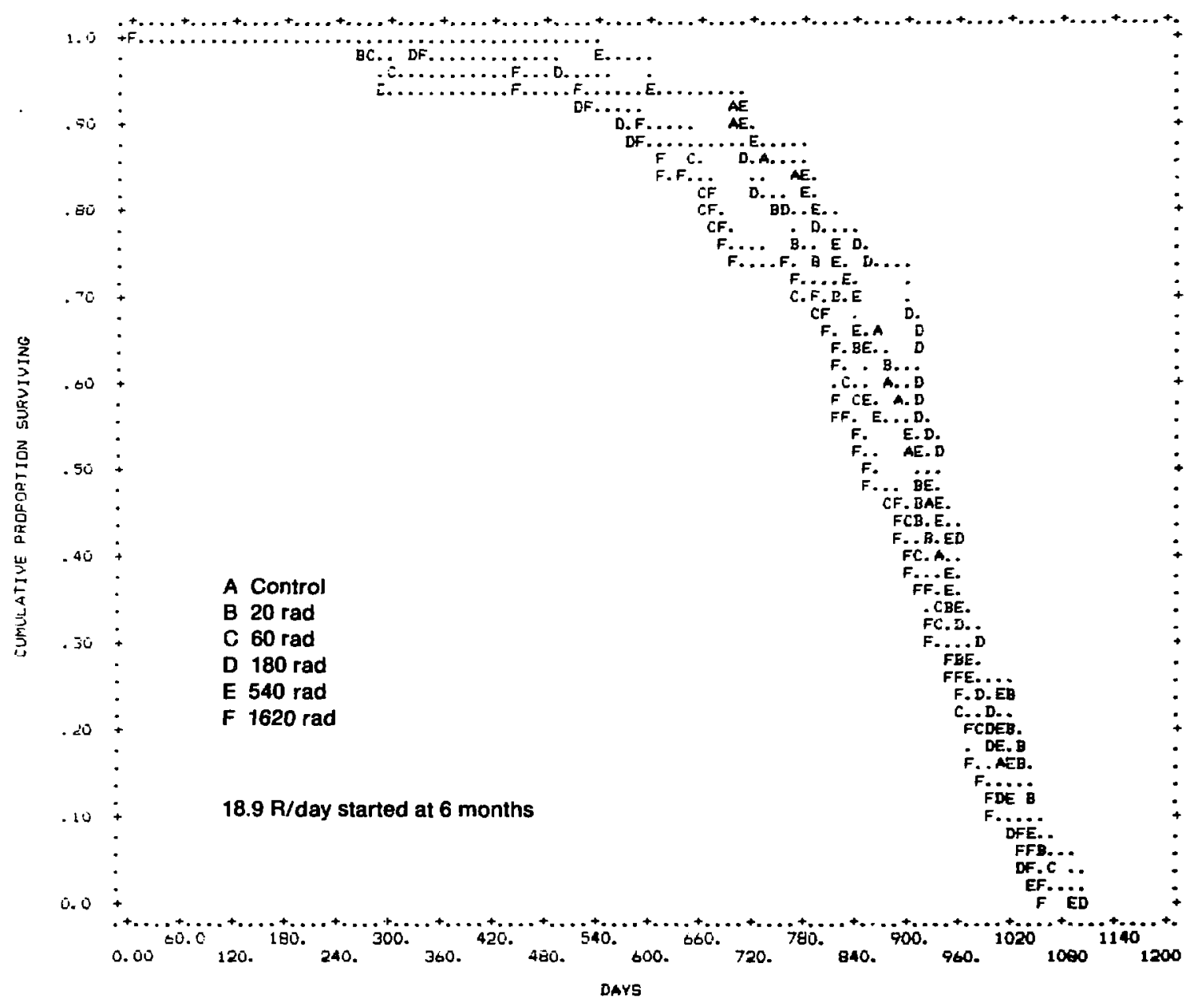

(m)

Fie. 1. (cont) 


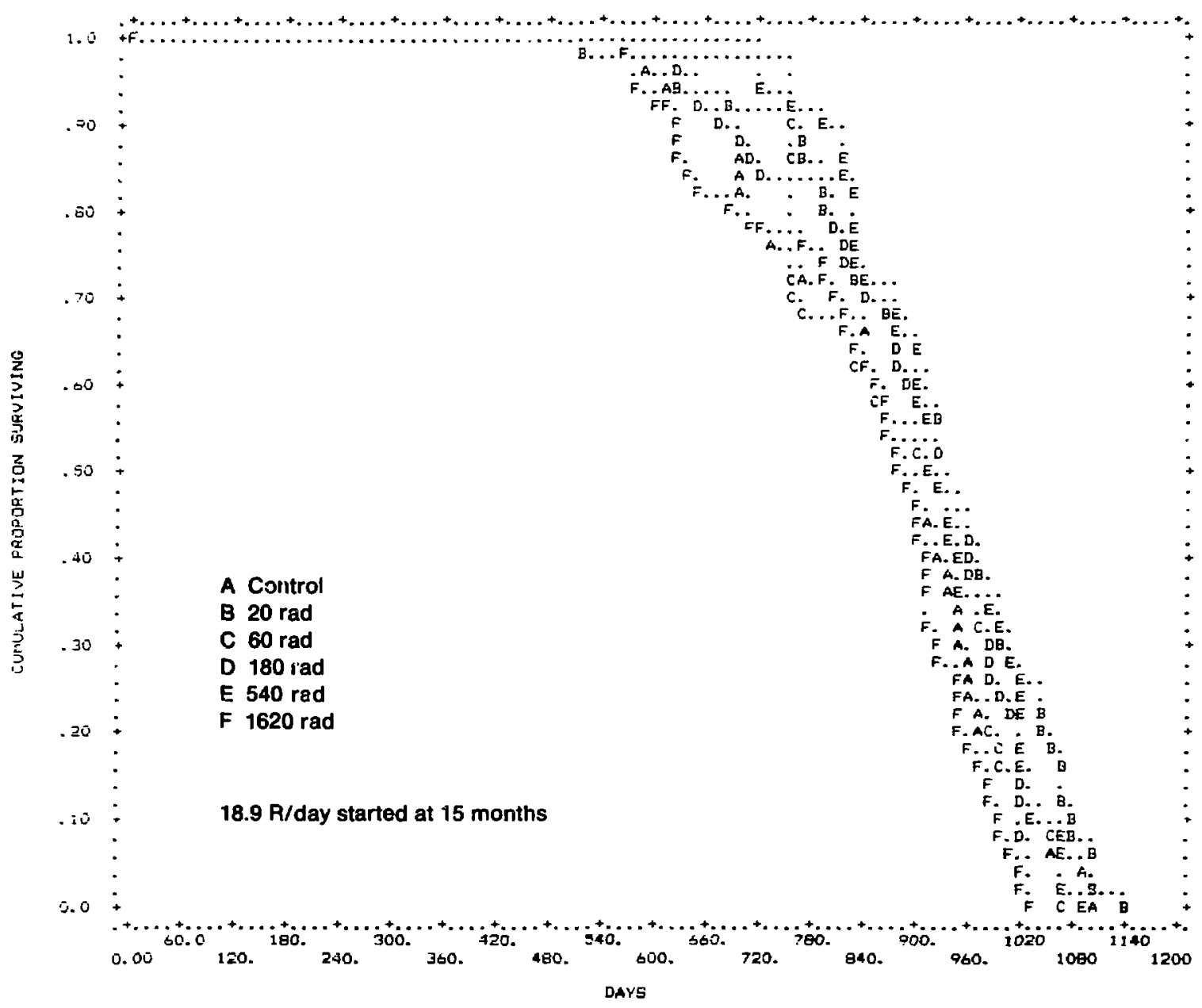

(n)

Fis. 1. (cont) 


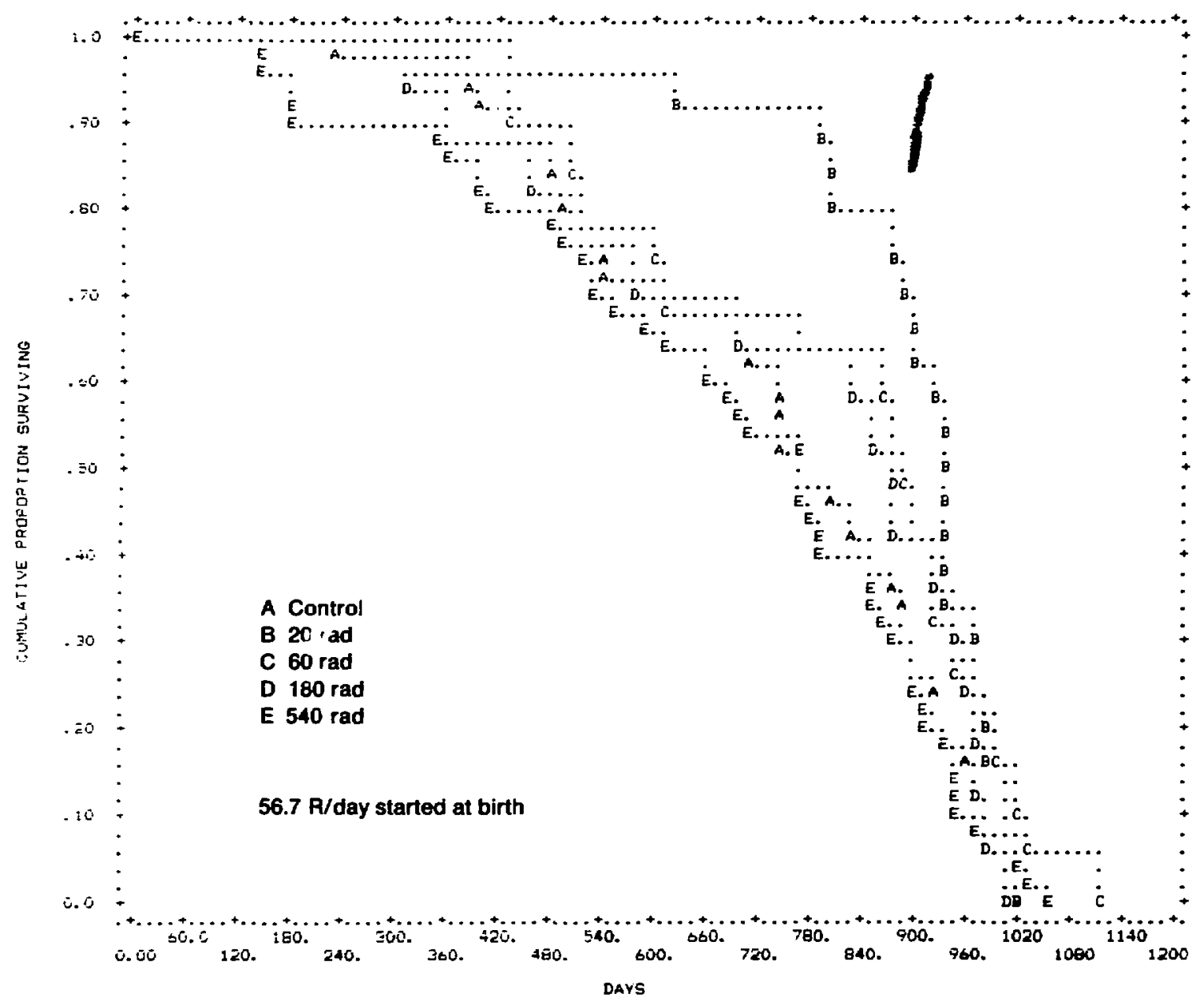

(o)

Fiz. 1. (cont) 


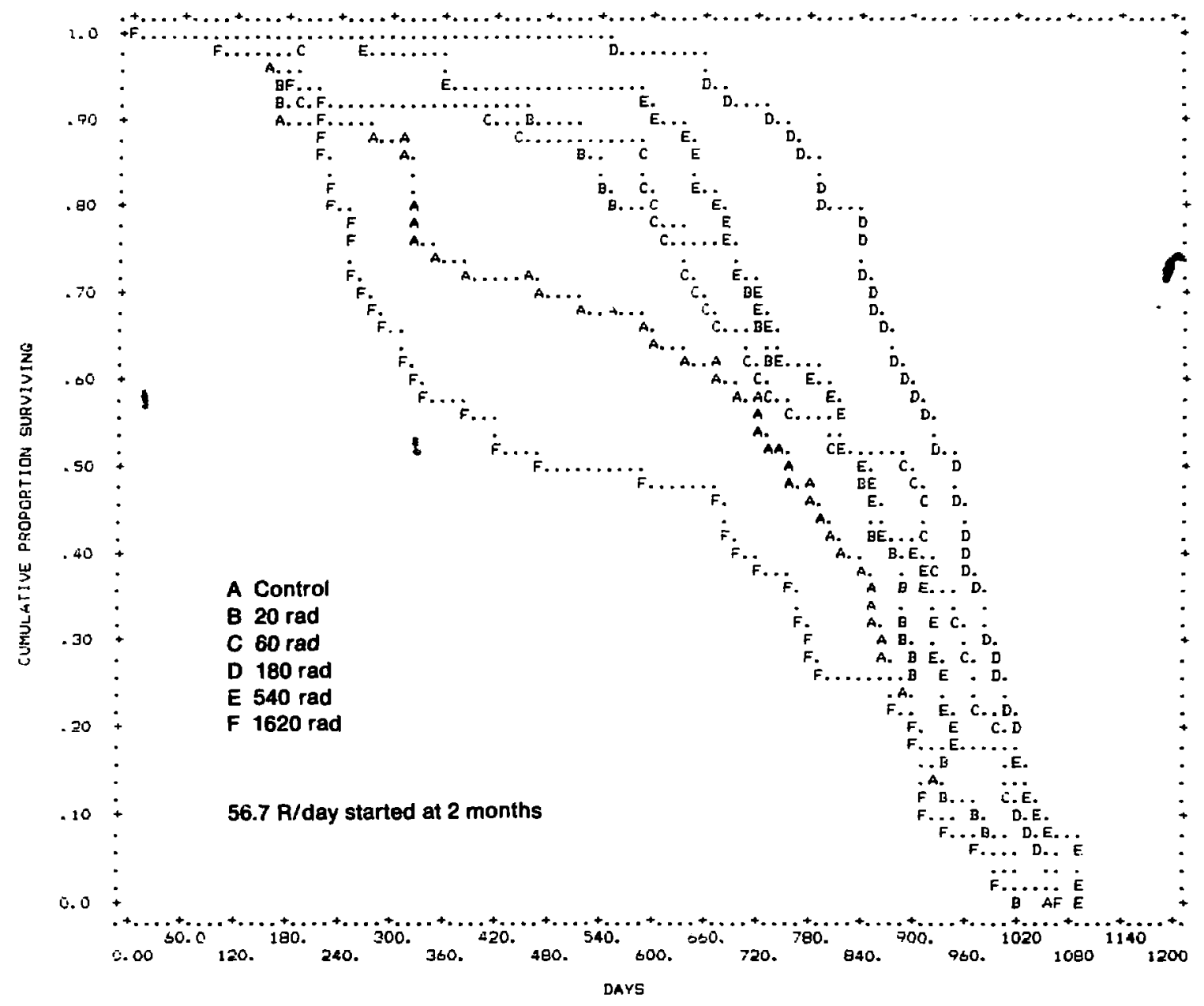

(p)

Fis. 1. (cont) 


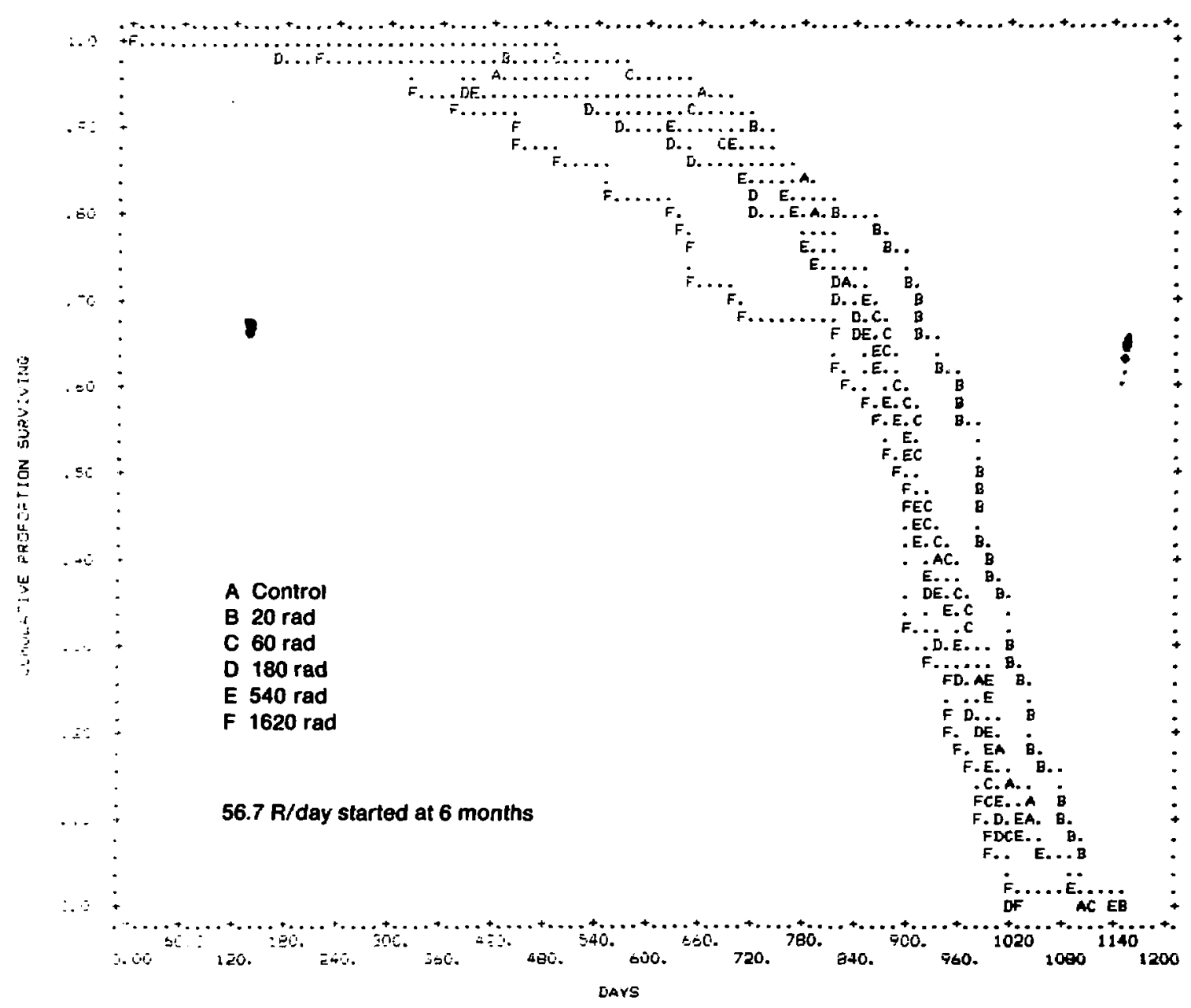

(q)

Fin. I. (cont) 


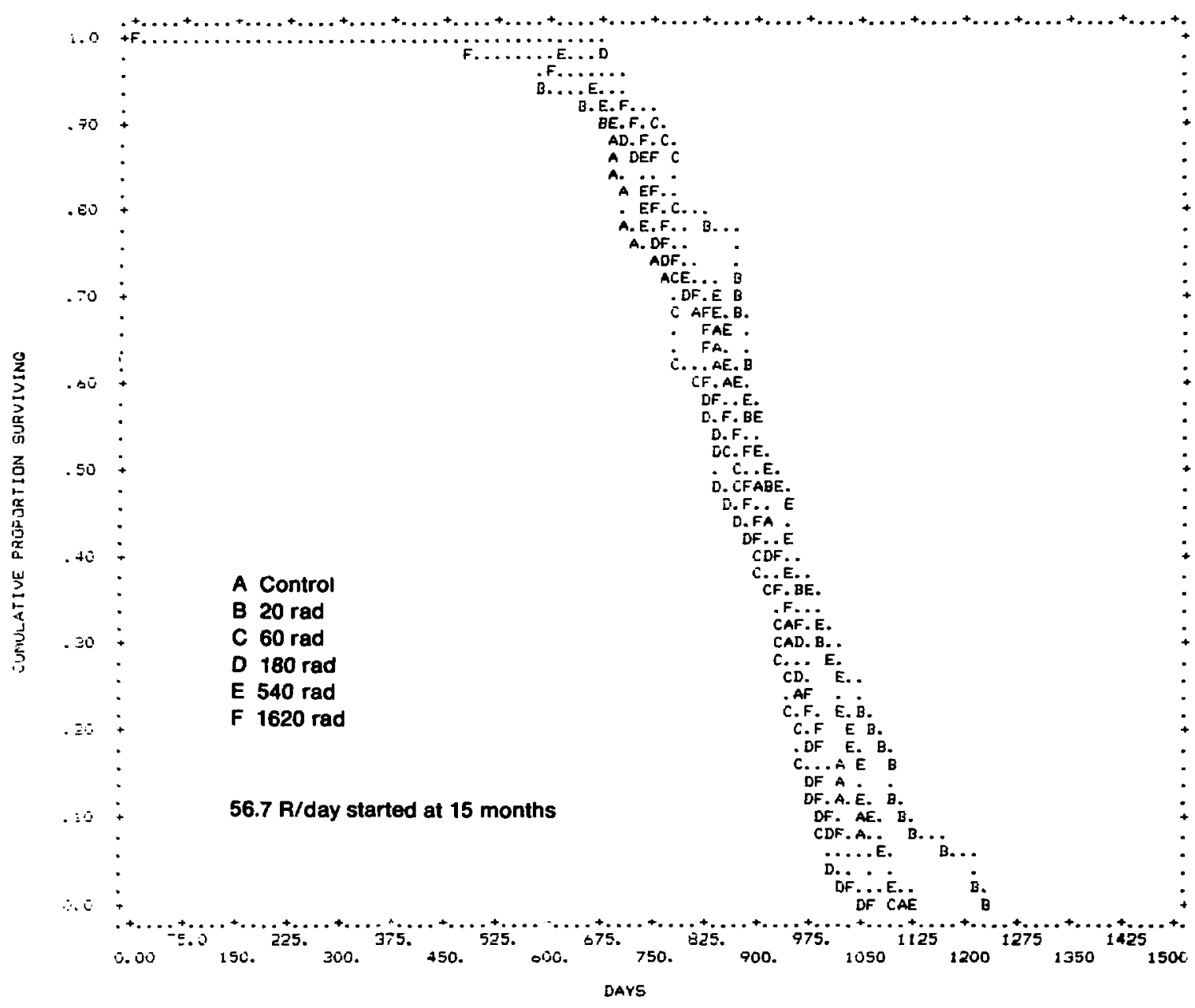

(r)

Fig. 1. (cont) 


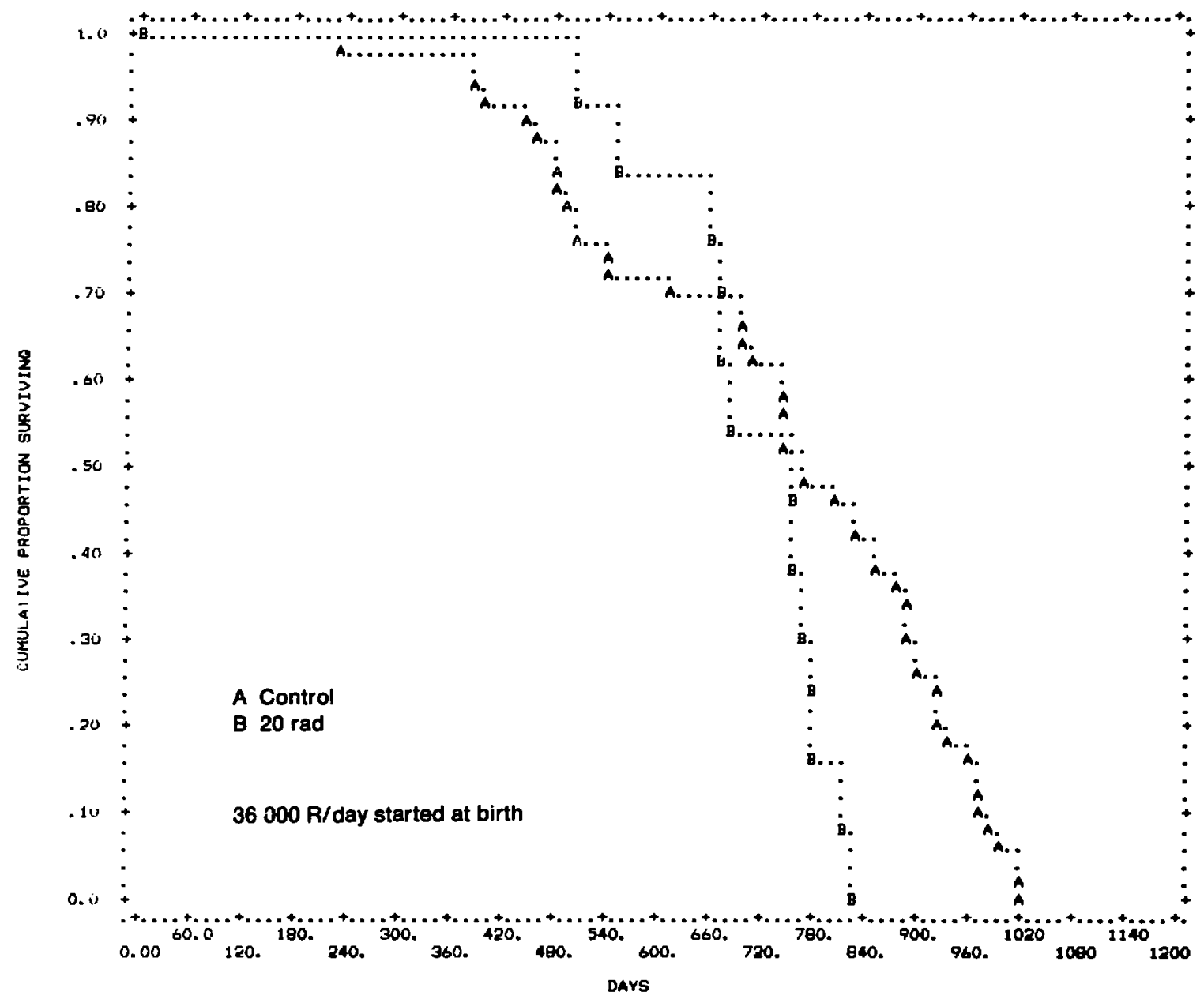

(s)

Fig. 1. (cont)

30 


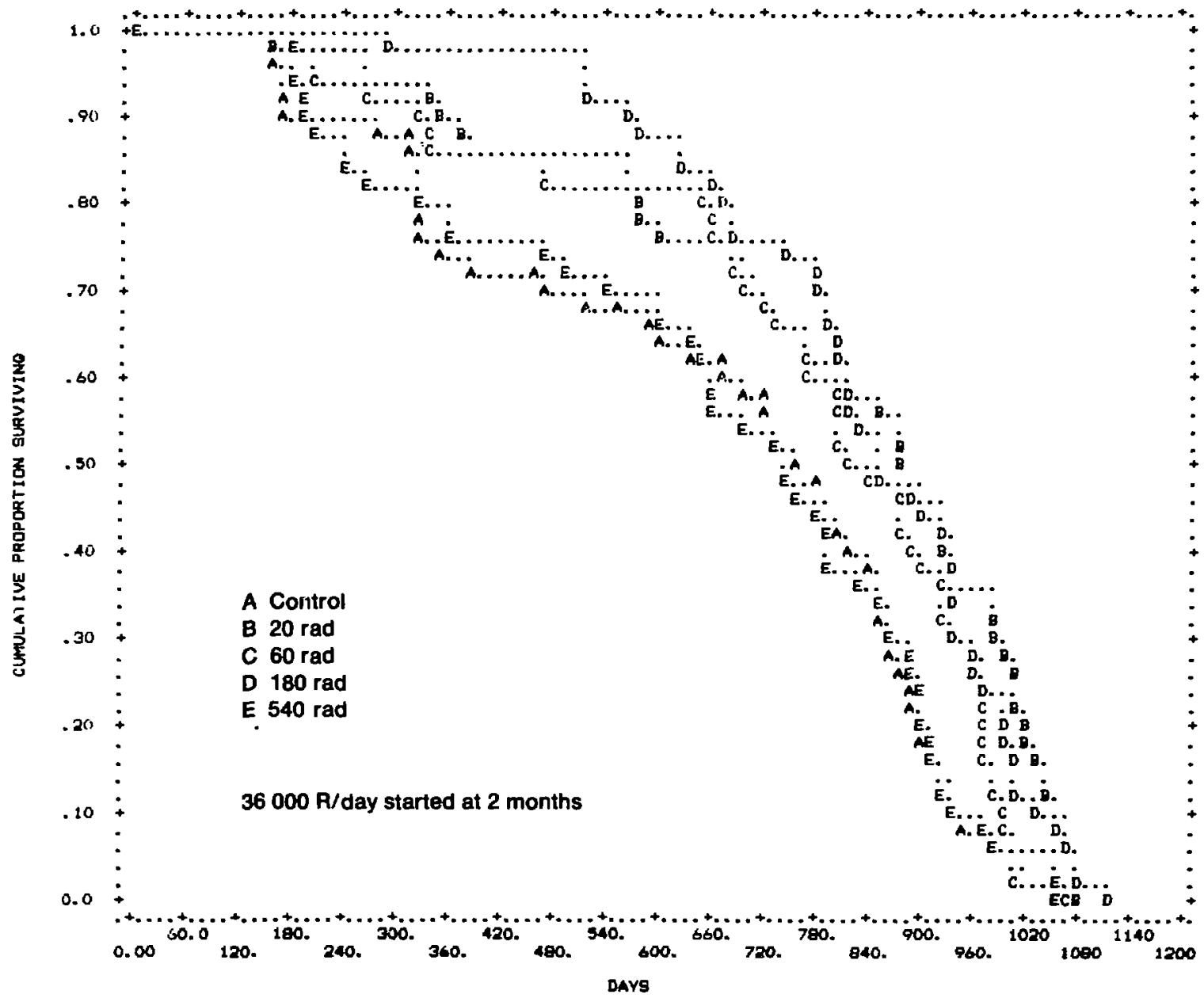

(t)

Fis. 1. (cont)

31 


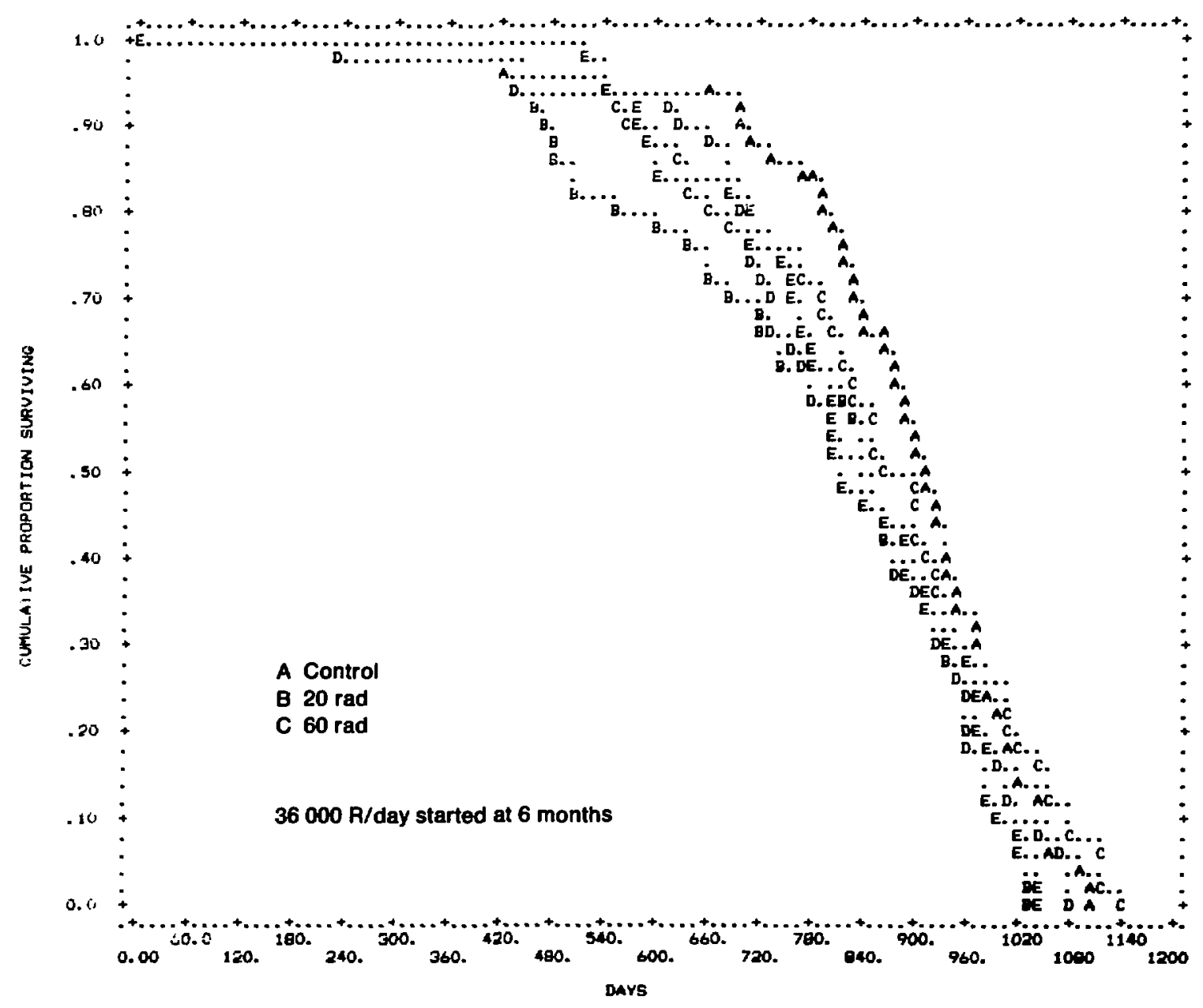

(u)

Fice. 1. (conx) 


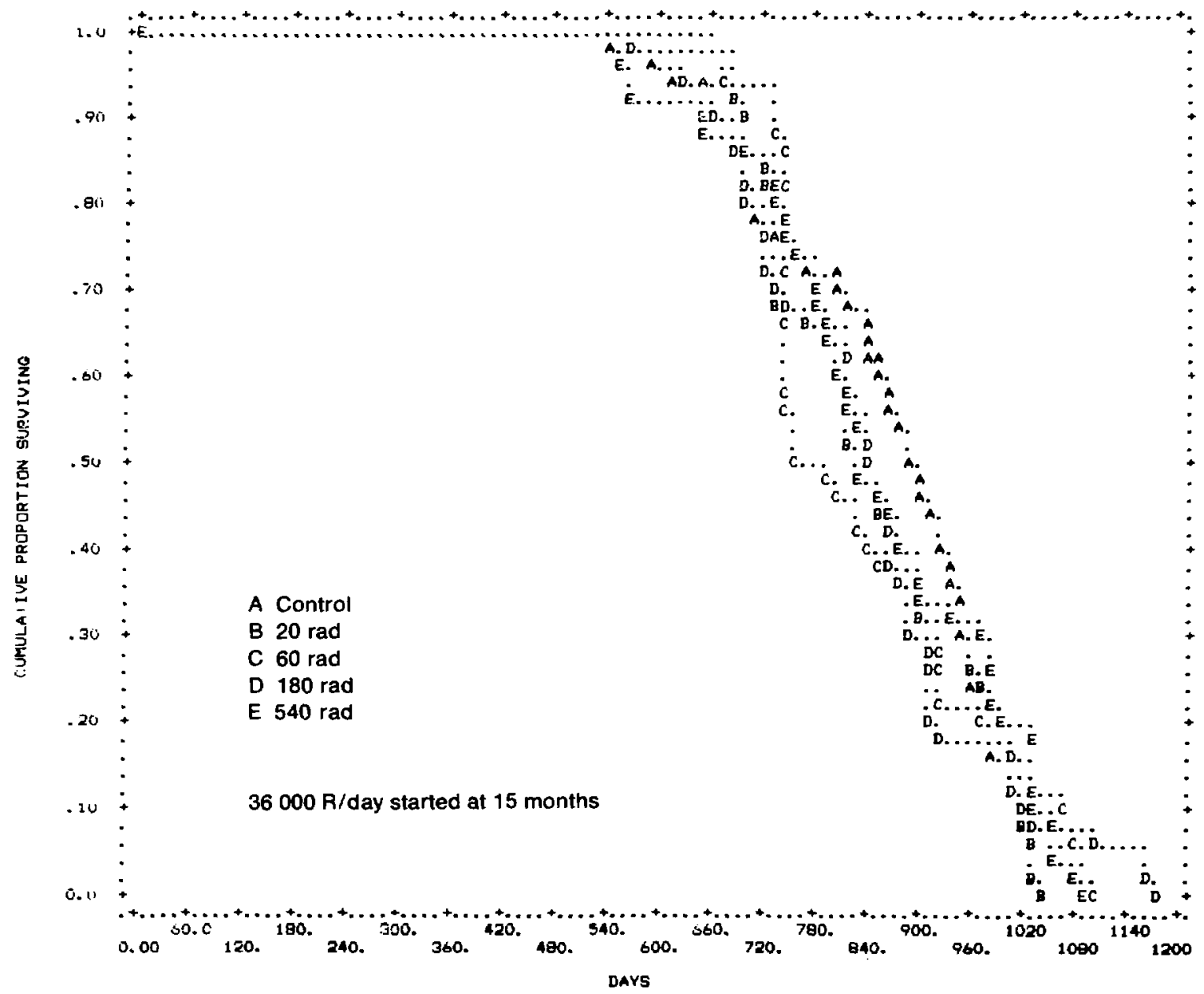

(v)

Fig. 1. (cont) 


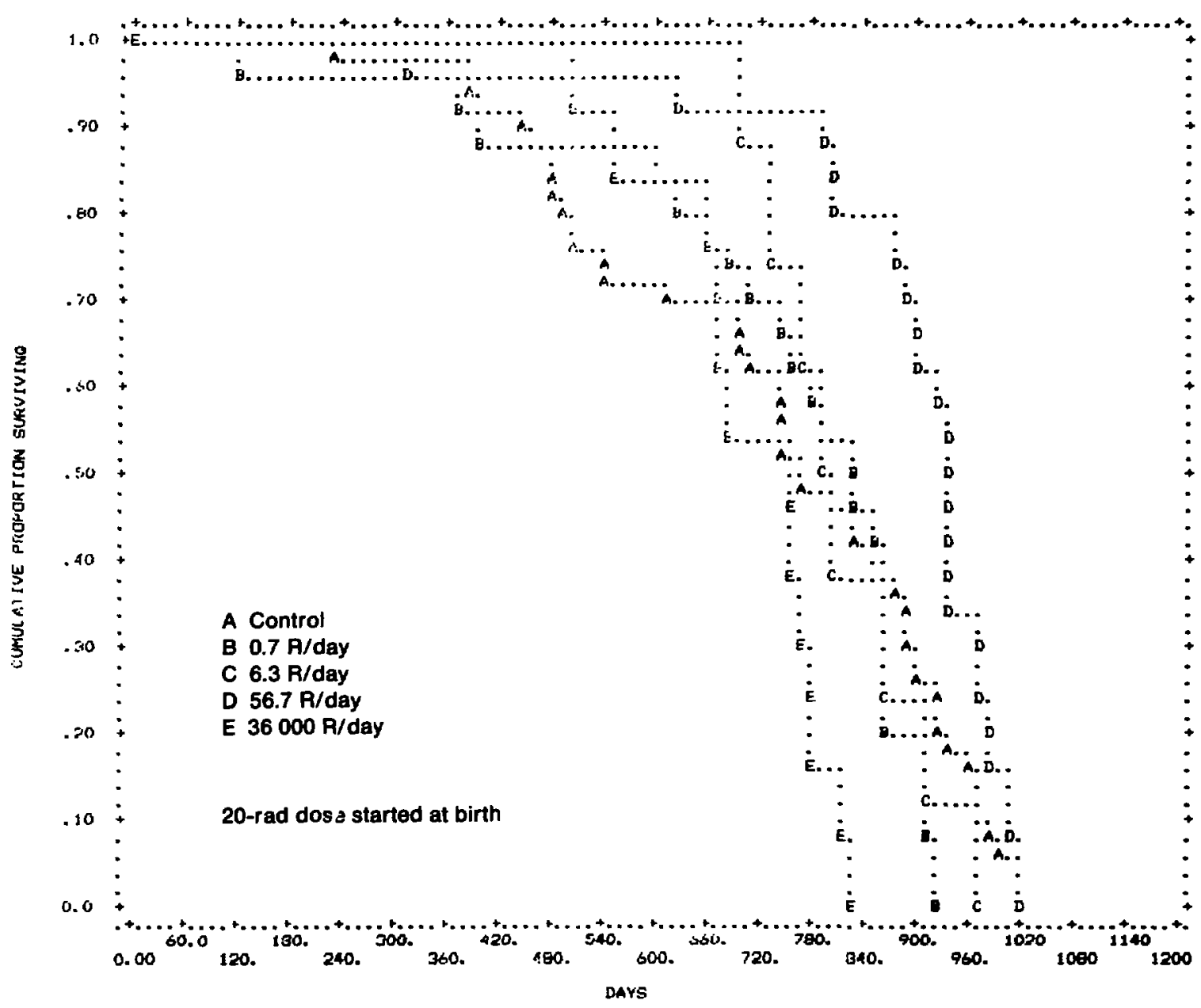

(a)

Fig. 2. (a)-(t). Cumulative proportion of mice surviving after specific gamma-ray dose at specified dose rates. 


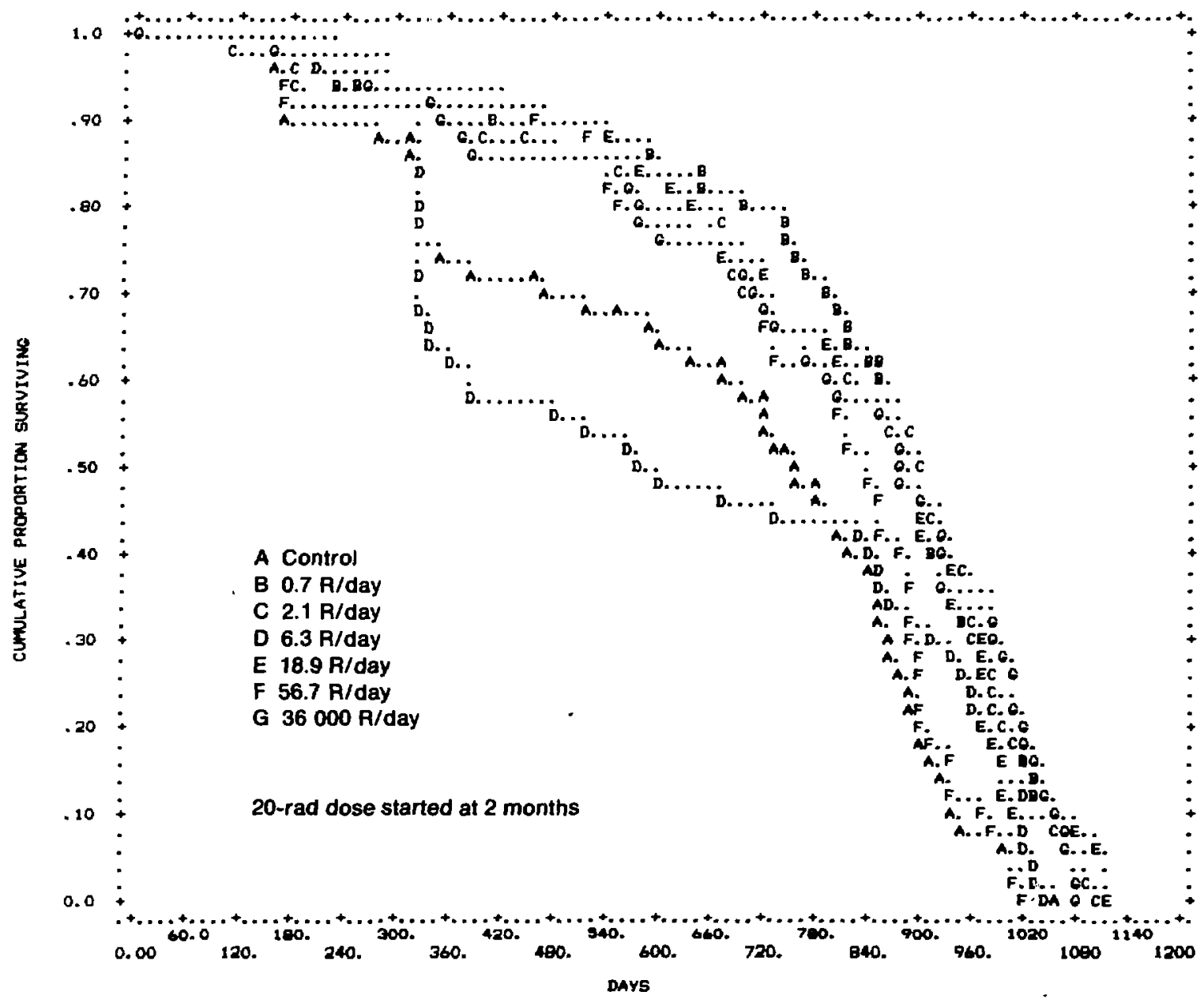

(b)

Fig. 2. (cont)

35 


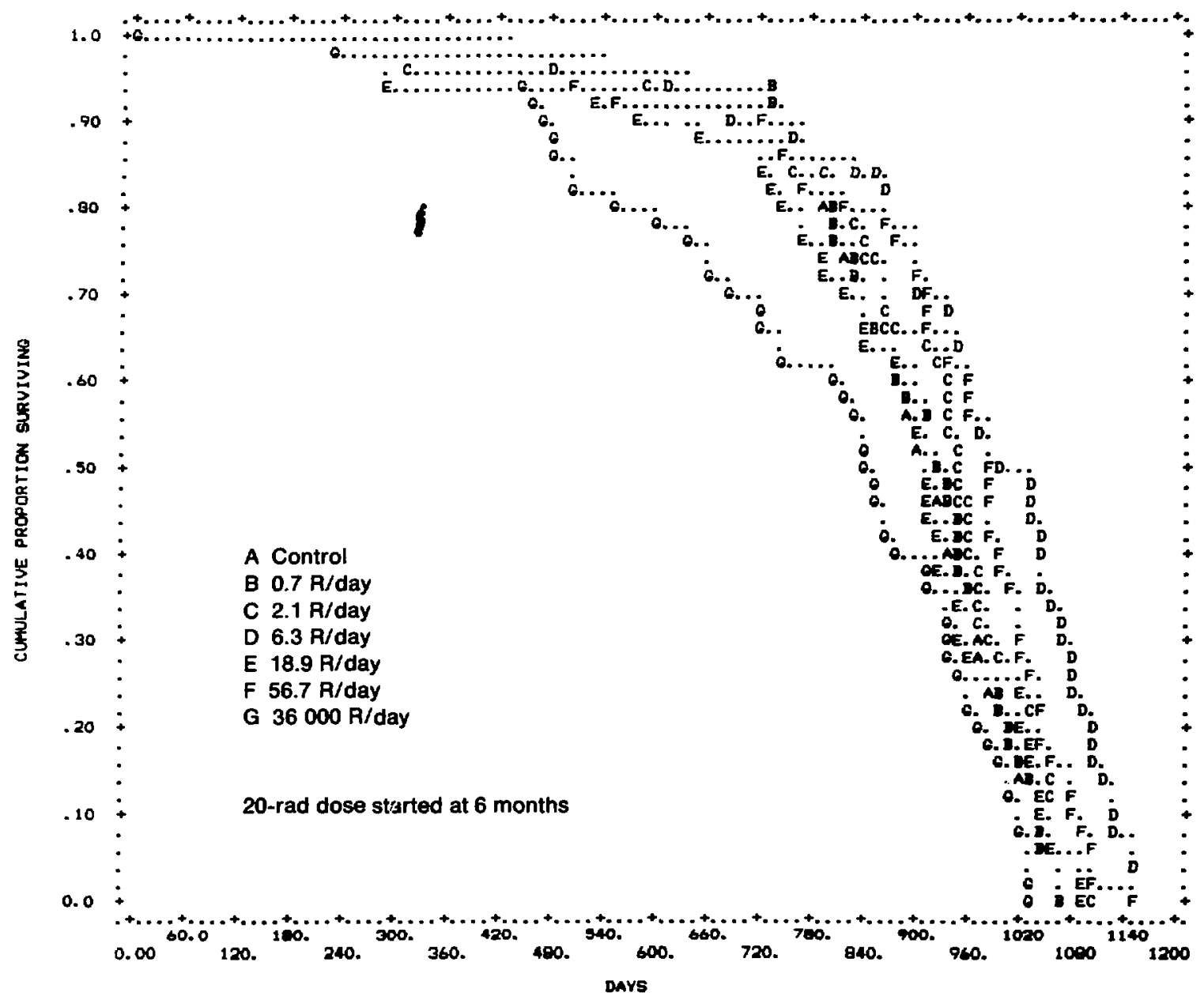

(c)

Fis. 2. (cont)

36 


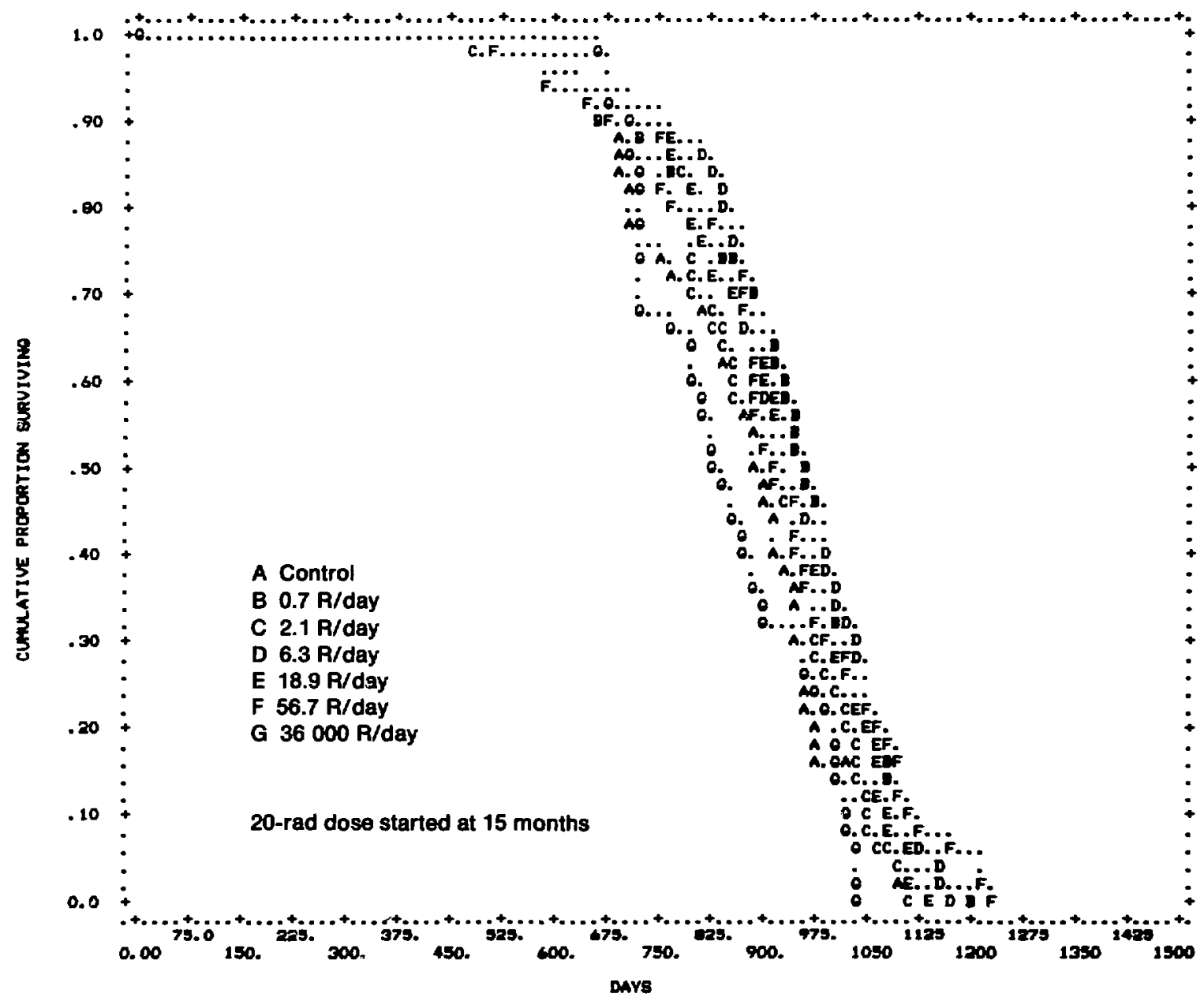

(d)

Fit. 2. (com)

37 


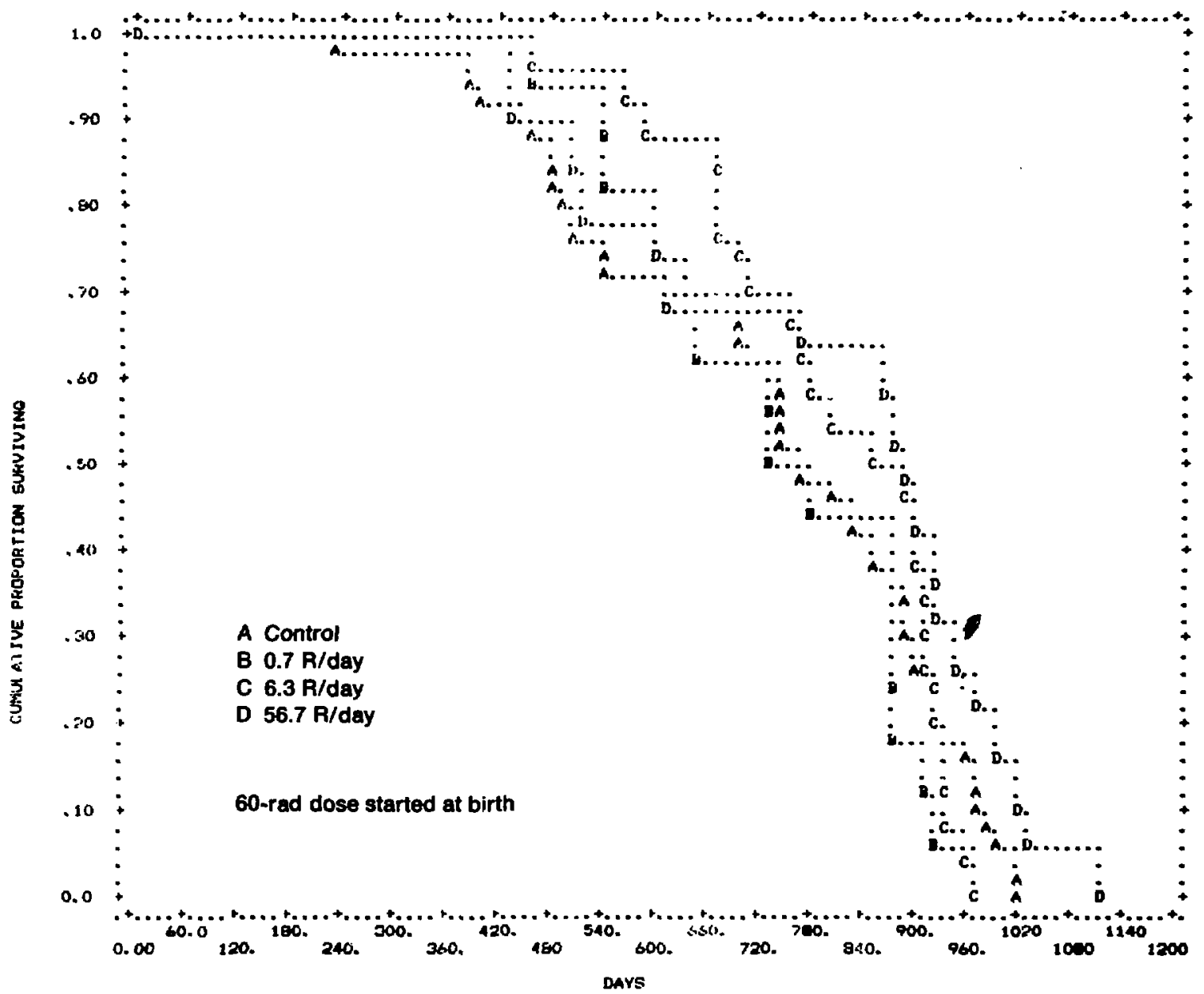

(e)

Fis. 2. (cont)

38 


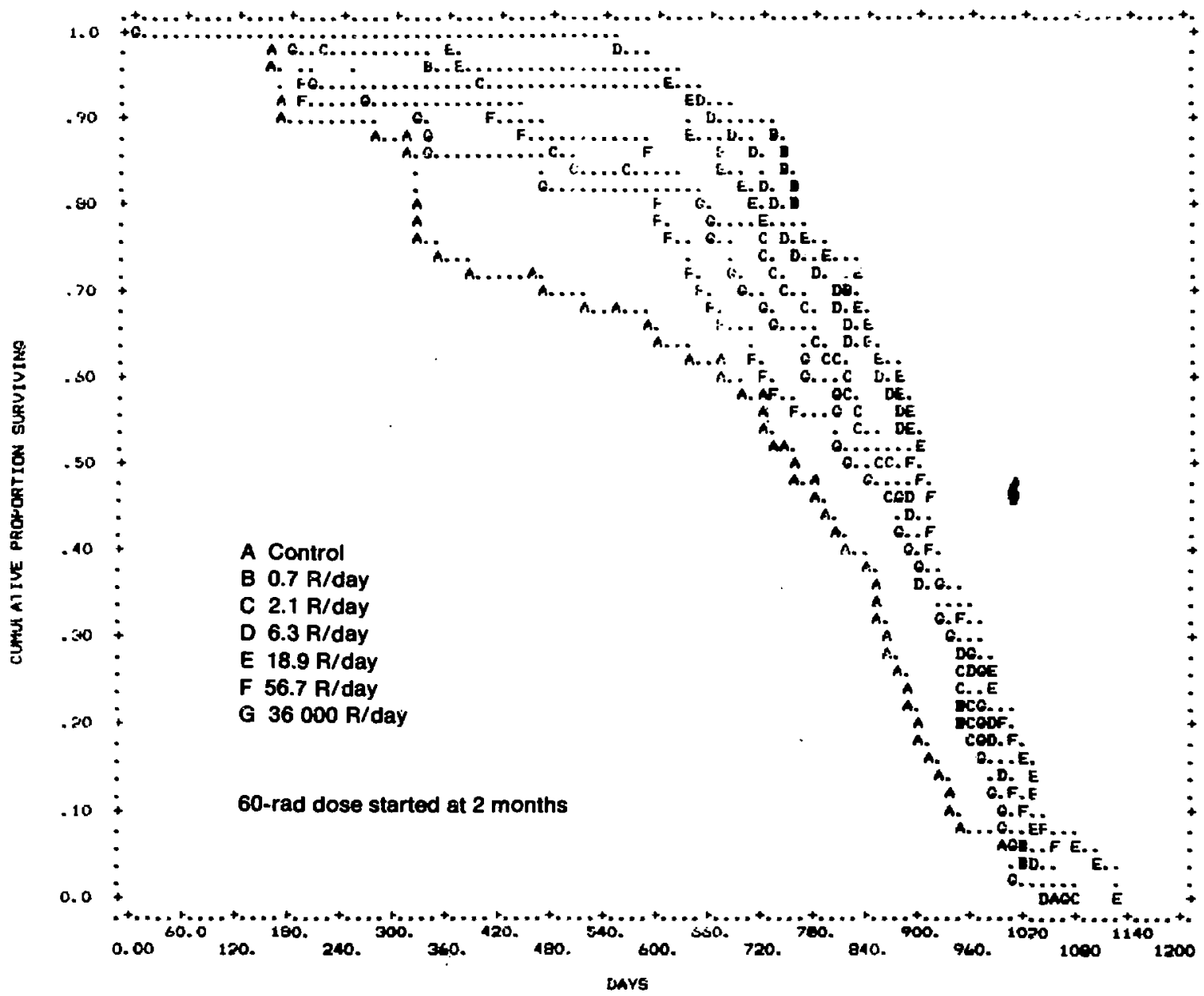

(n)

Fie. 2 (cont)

39 


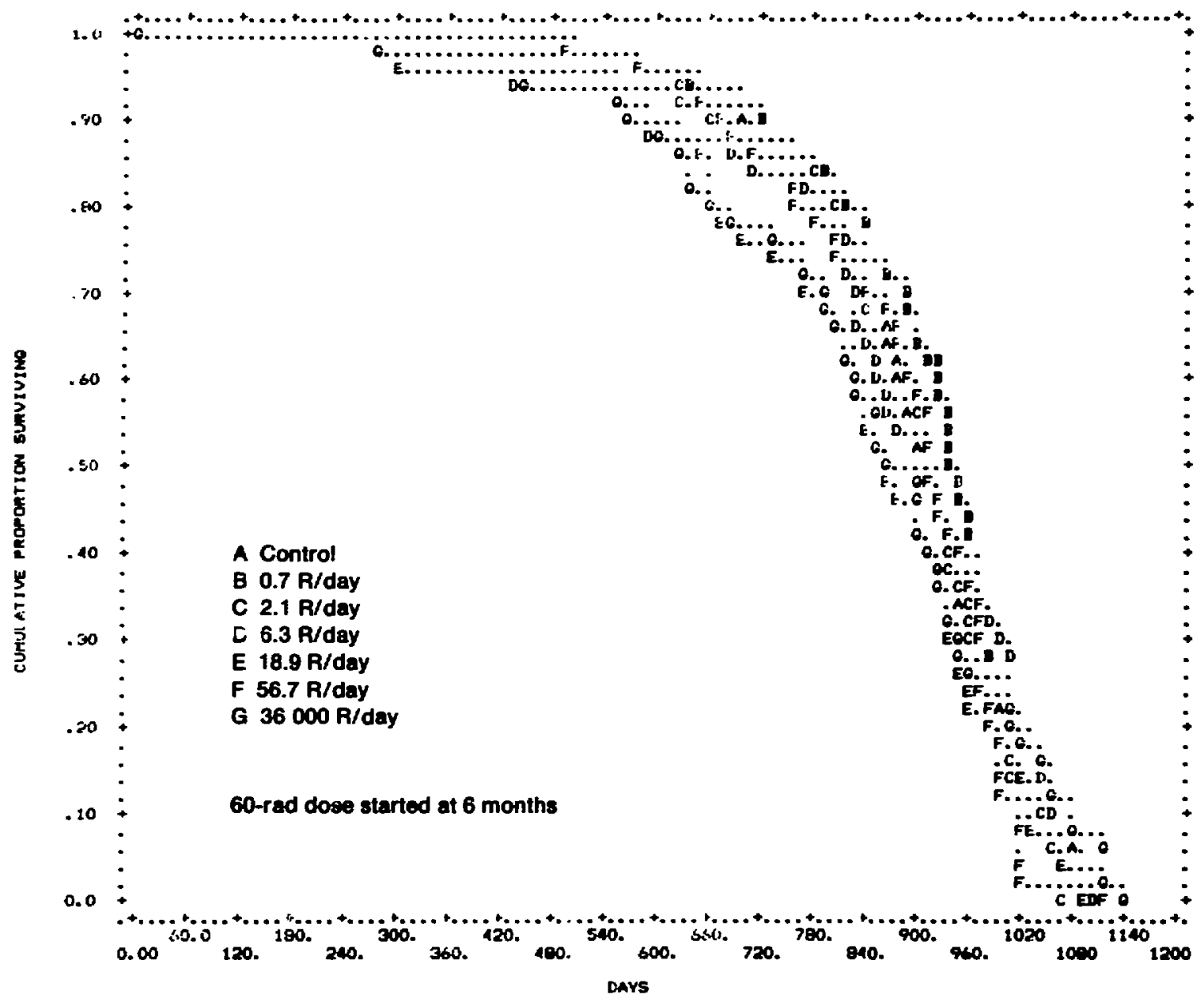

(s)

Fit 2 (com)

40 


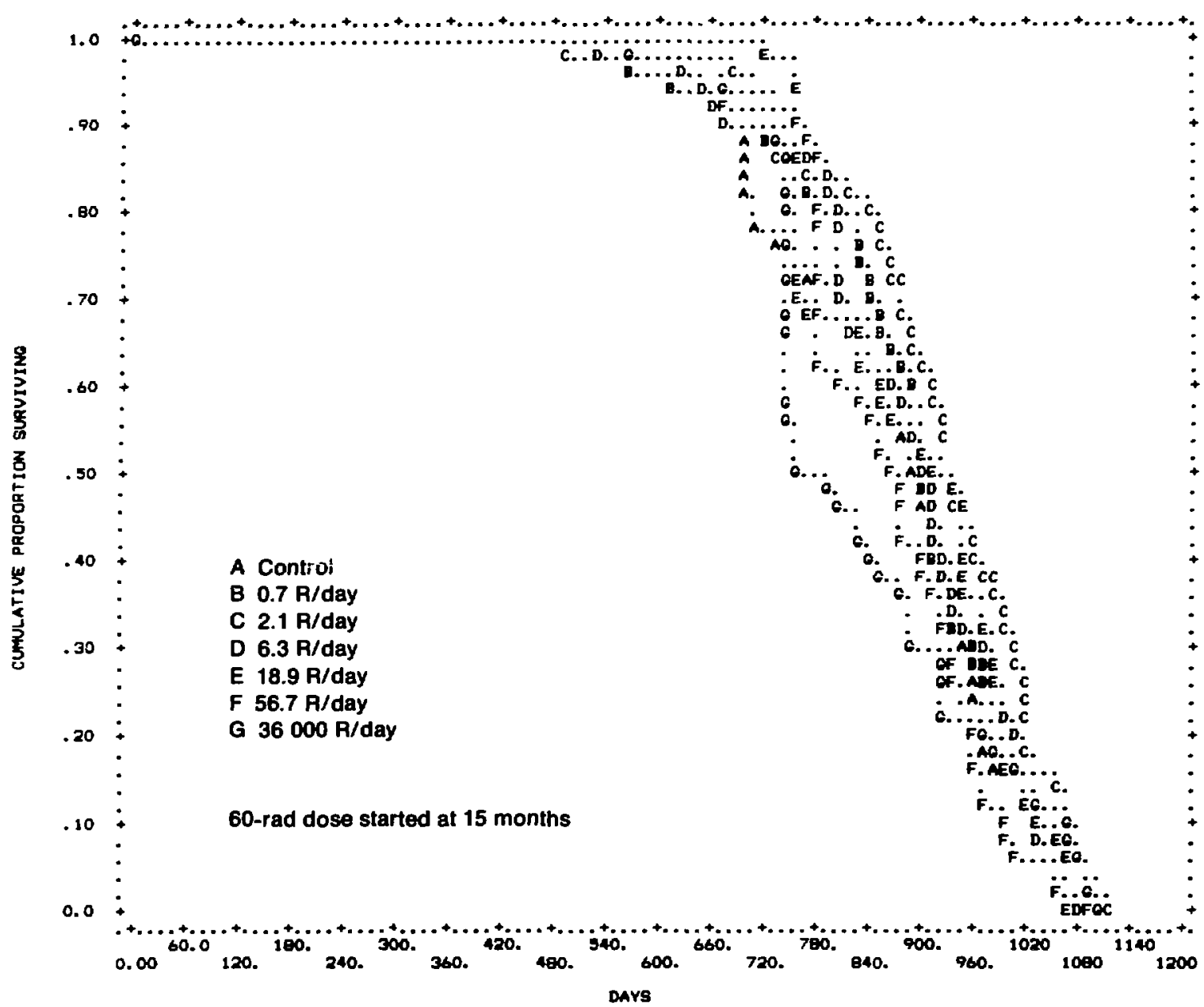

(h)

Fig. 2. (cont) 


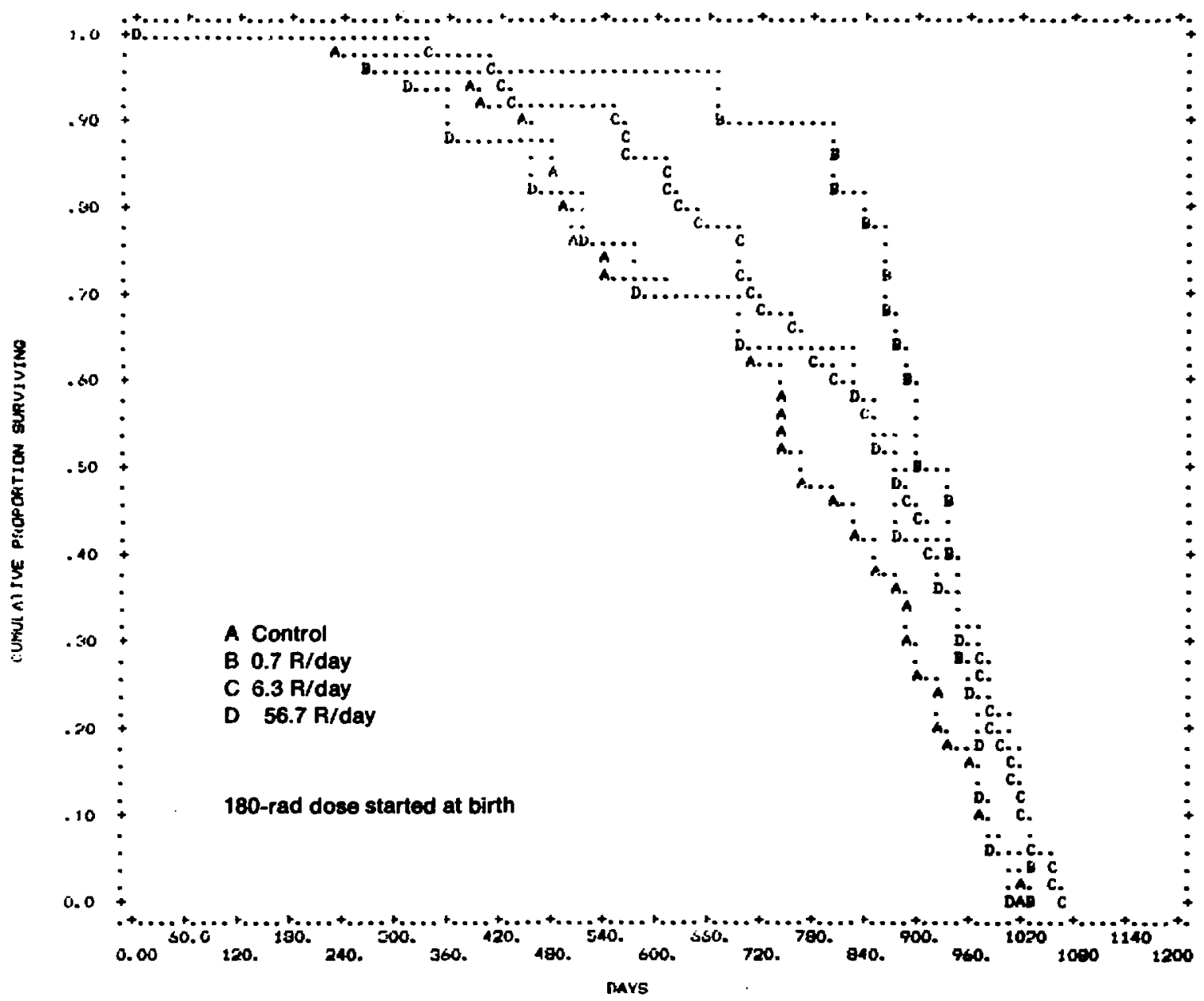

(i)

Fig. 2. (com)

42 


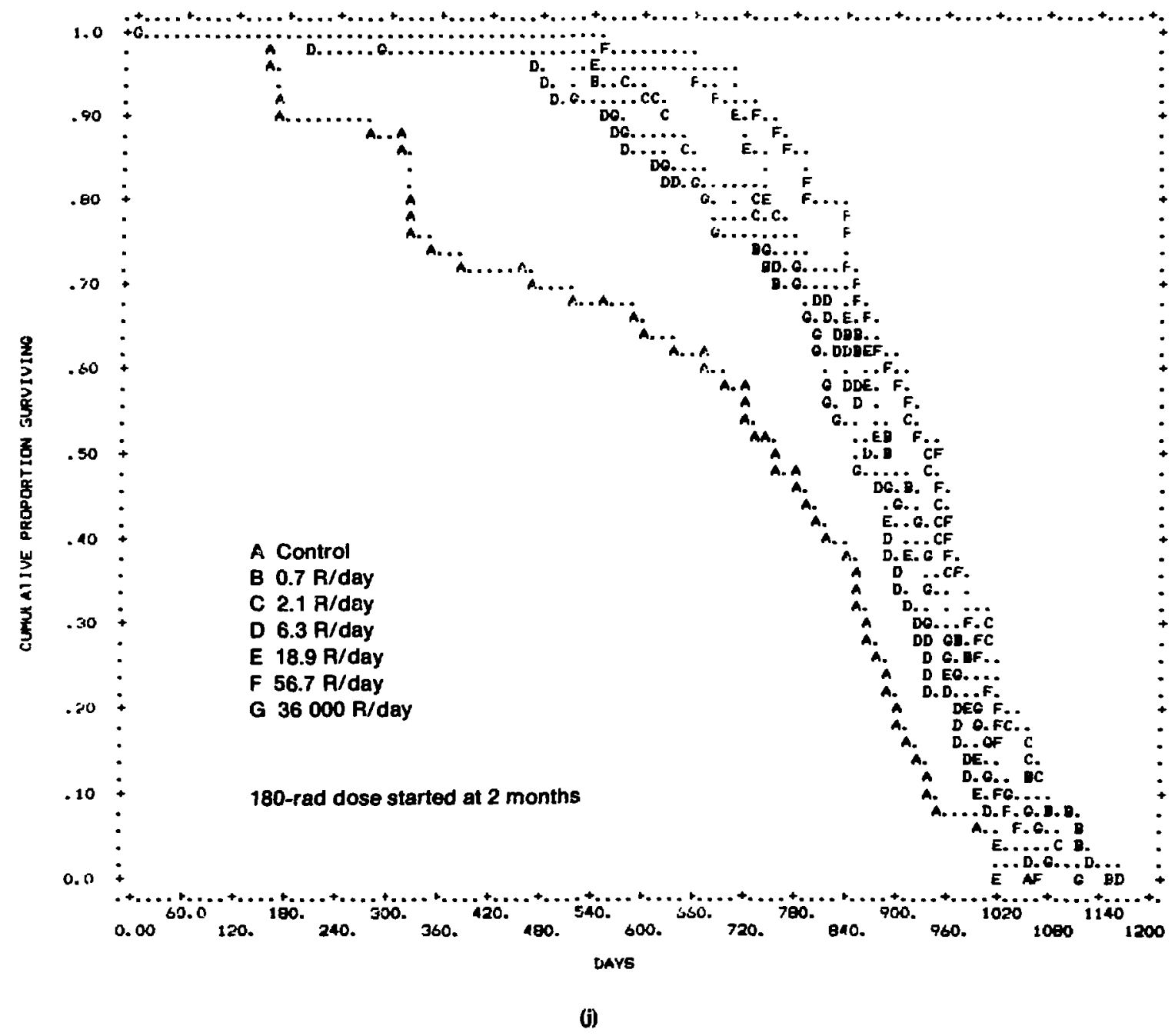

Fis. 2. (cont) 


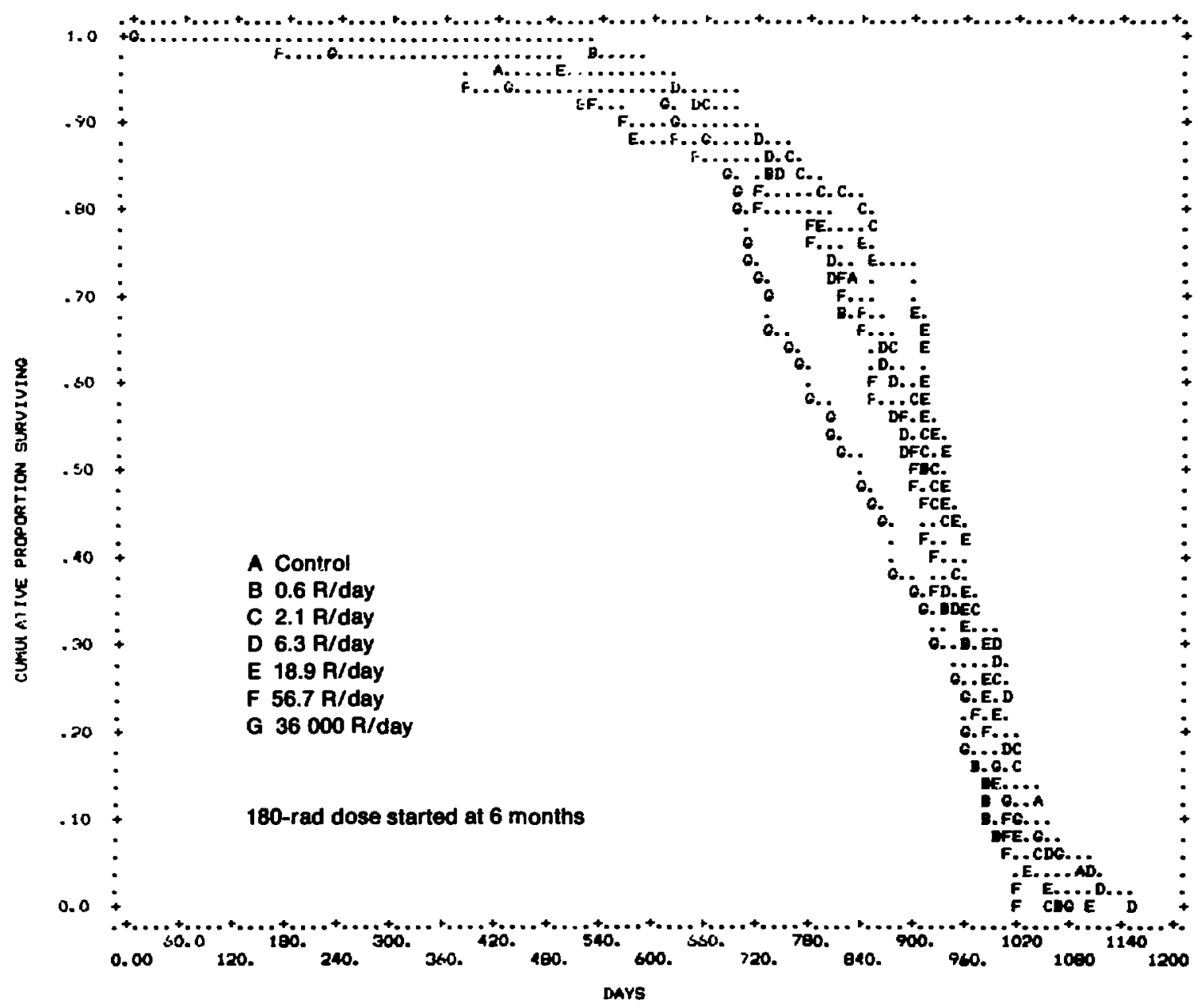

(k)

Fit $2 .(\mathrm{com})$ 


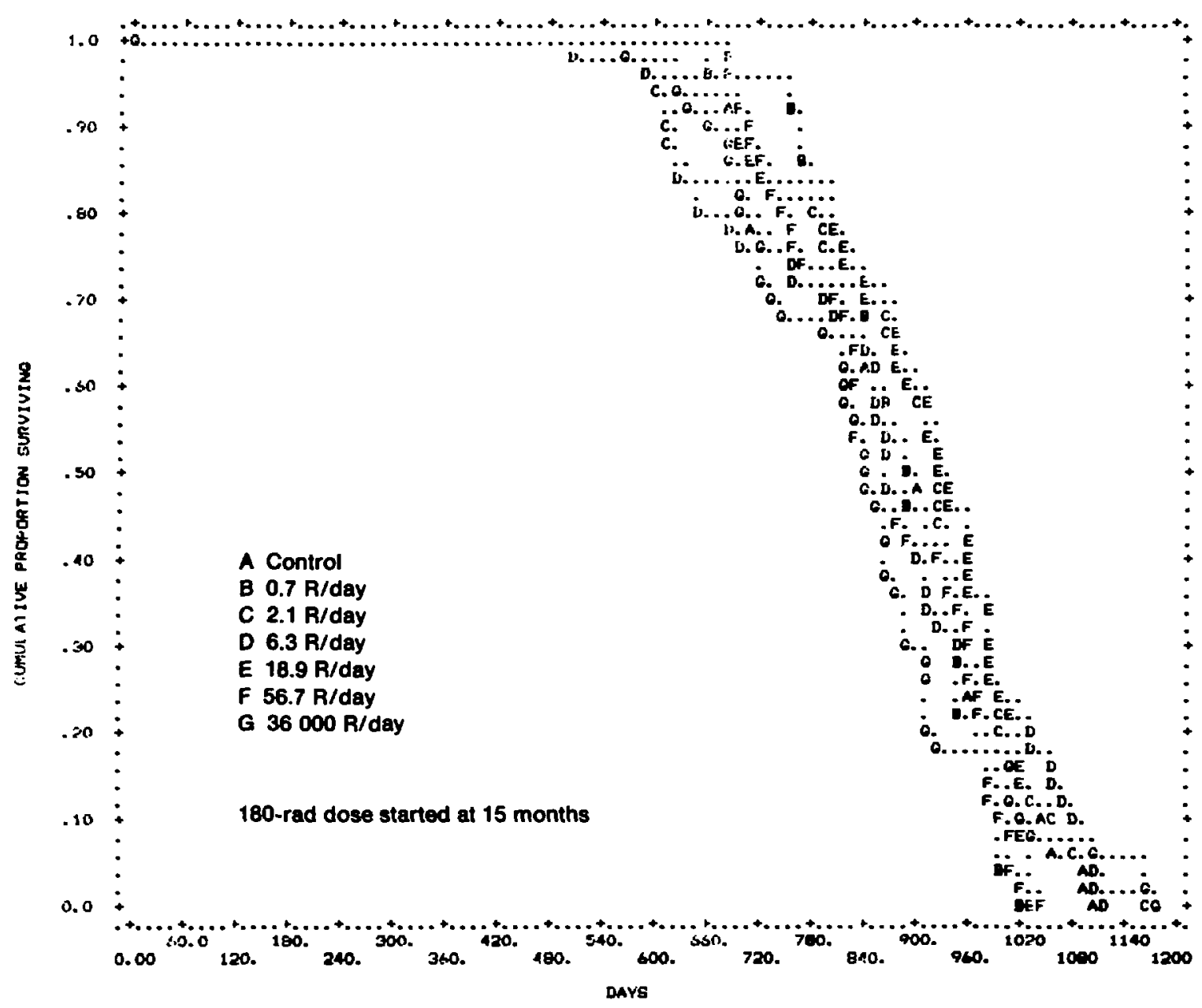

(I)

Fto. 2. (coms) 


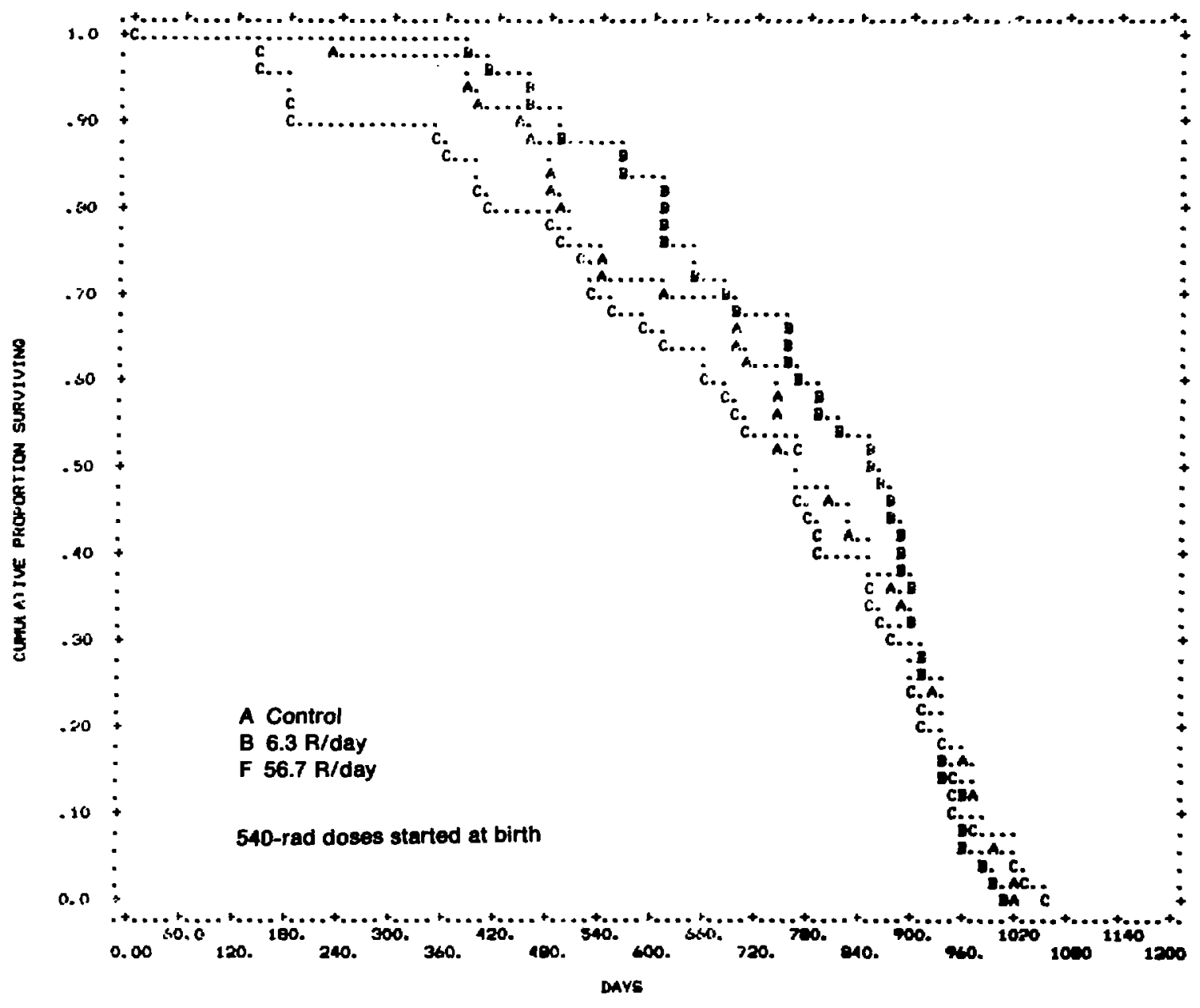

(m)

Fig. 2. (cont) 


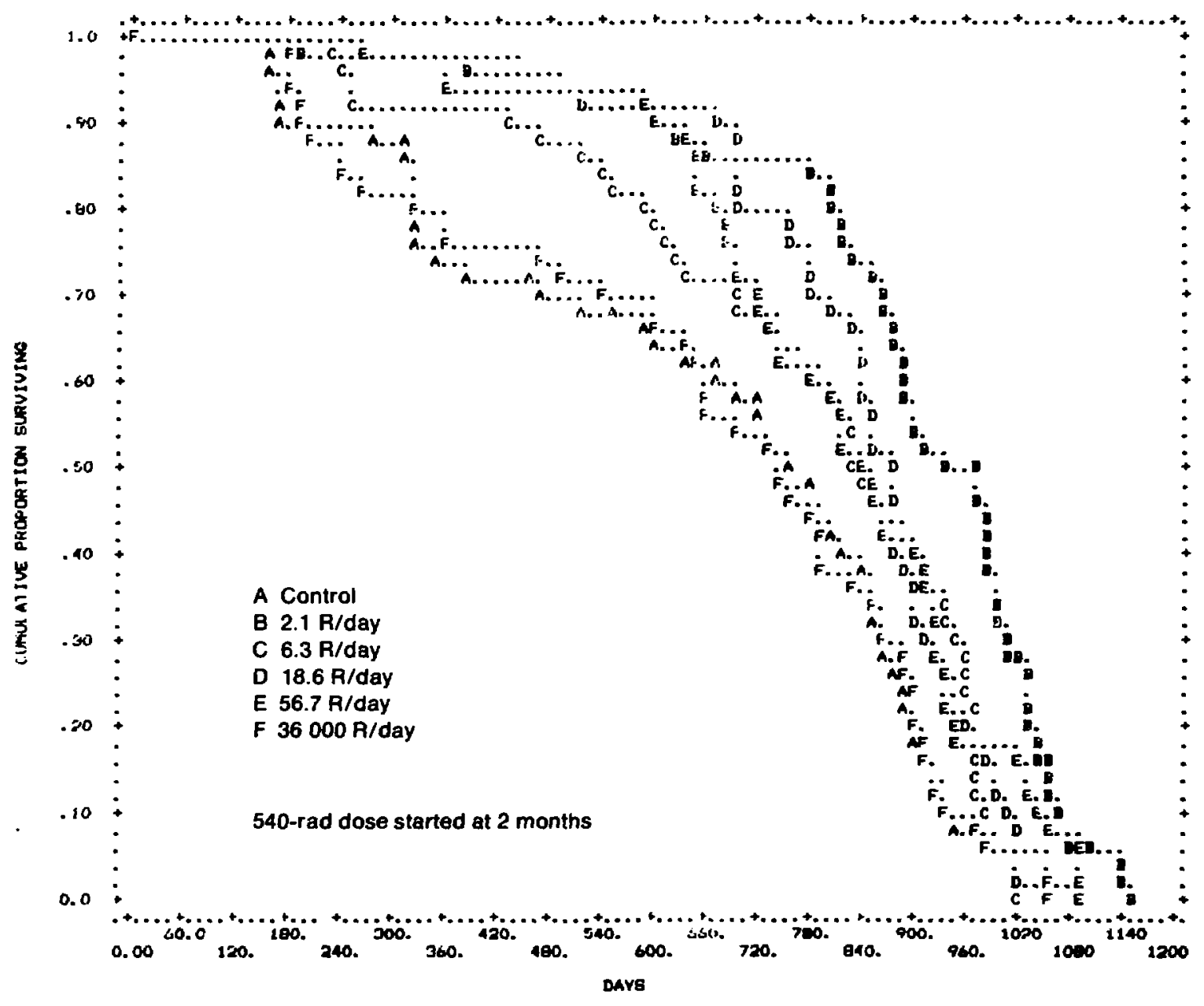

(n)

Fis. 2. (cont) 


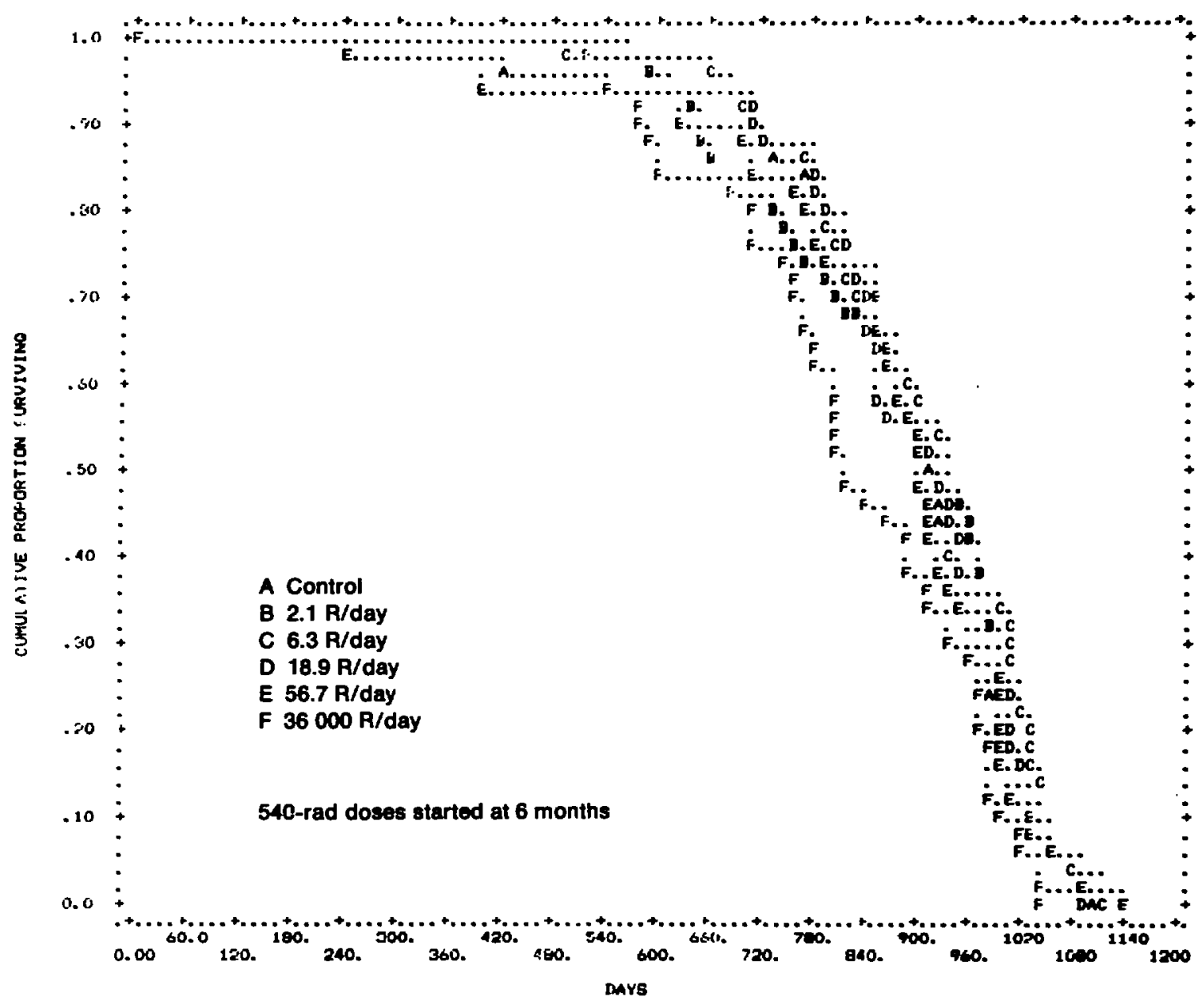

(o)

Fis, 2. (com) 


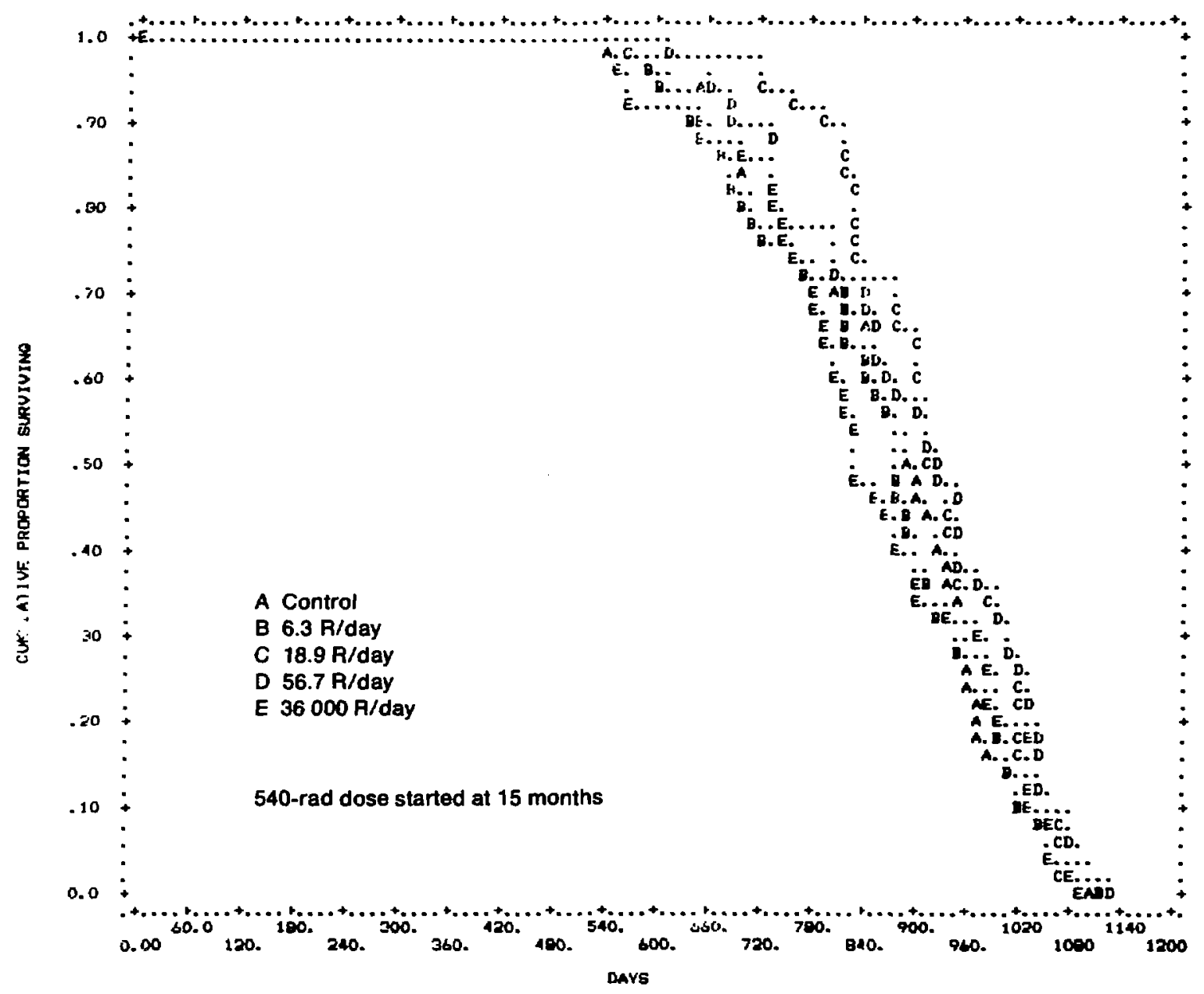

(p)

Fig. 2. (com) 


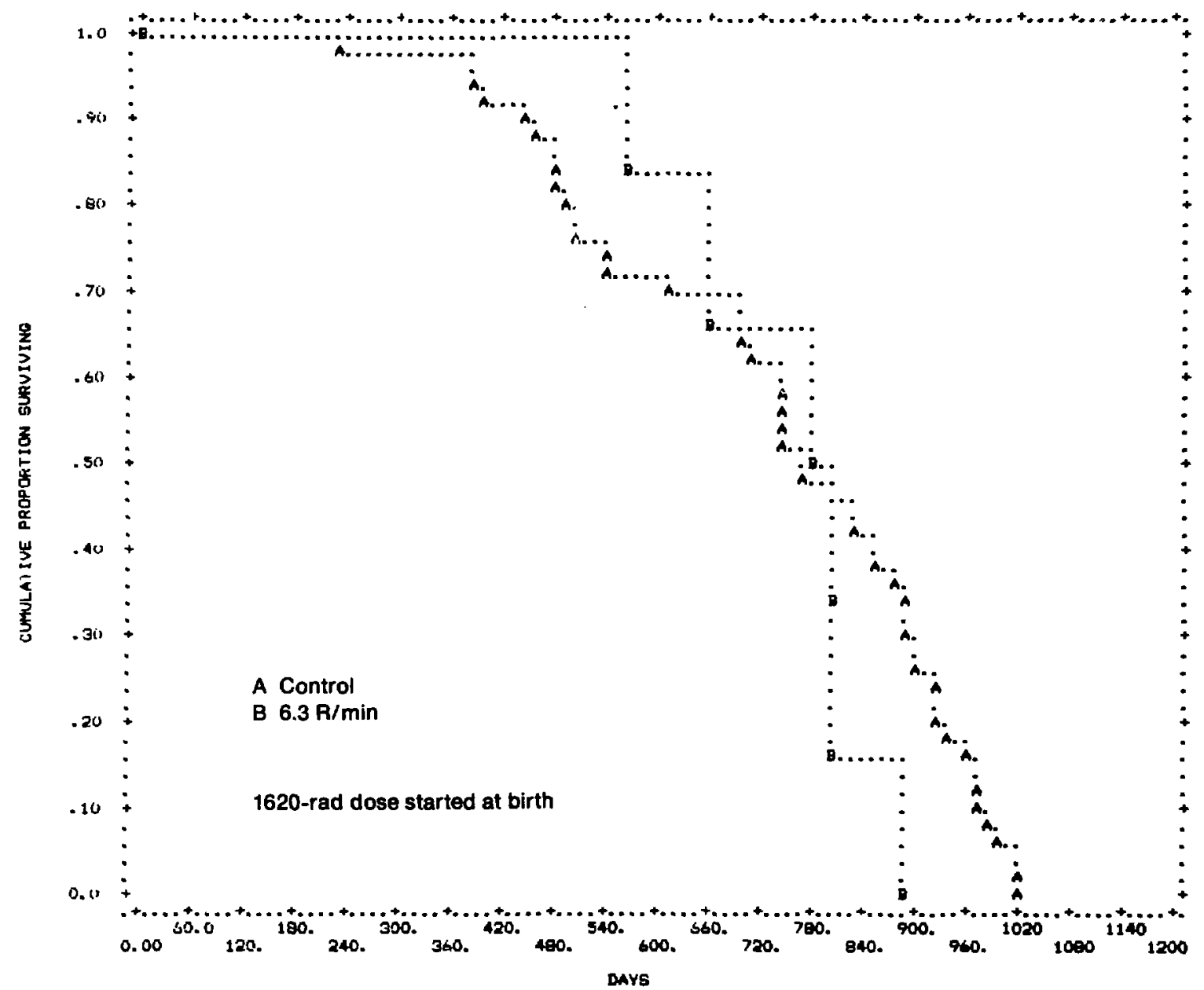

(q)

Fiz. 2. (cont)

50 


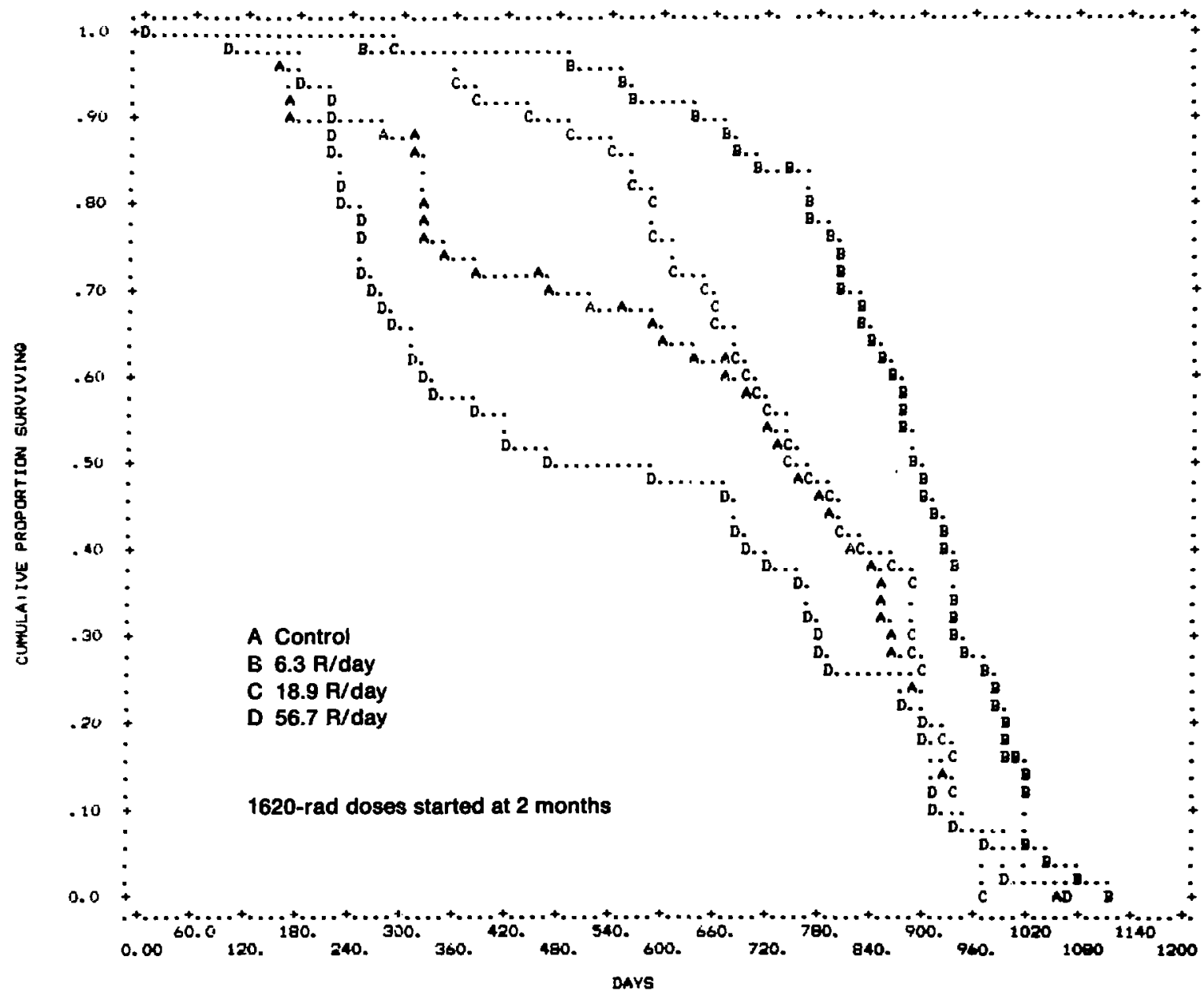

(r)

Fic. 2. (cont)

51 


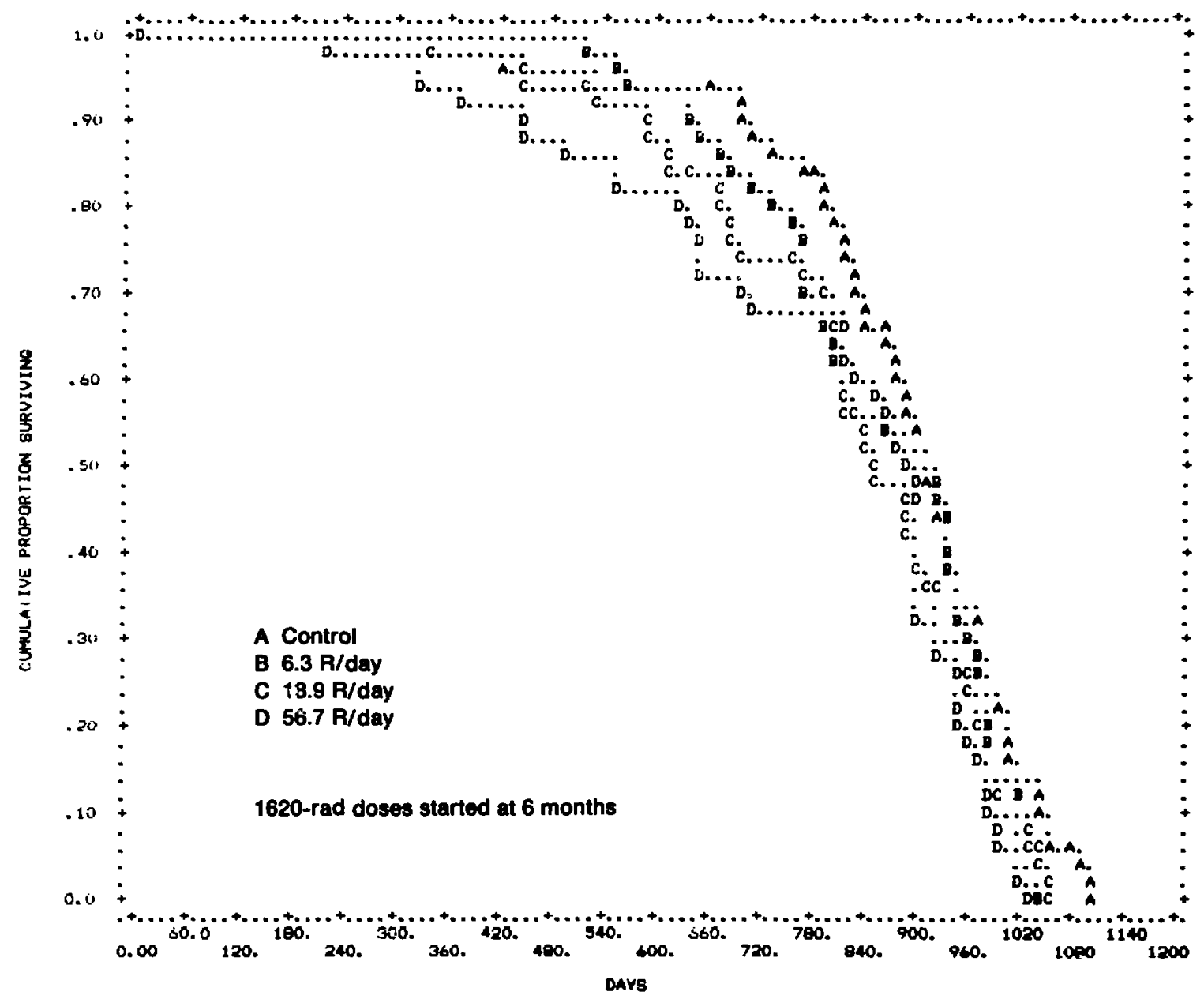

(a)

Fig. 2. (cont) 


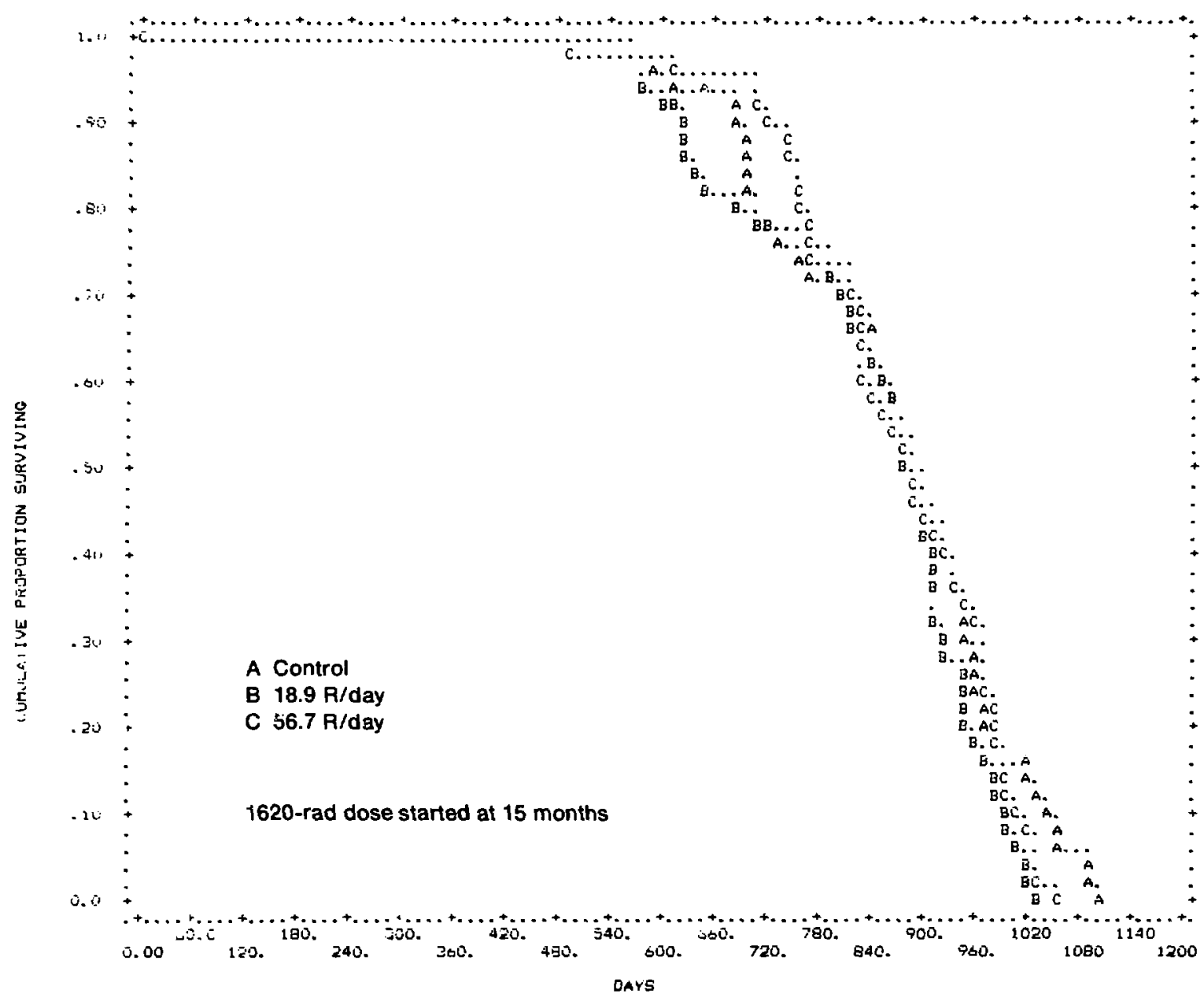

(t)

Fig. 2. (cont) 


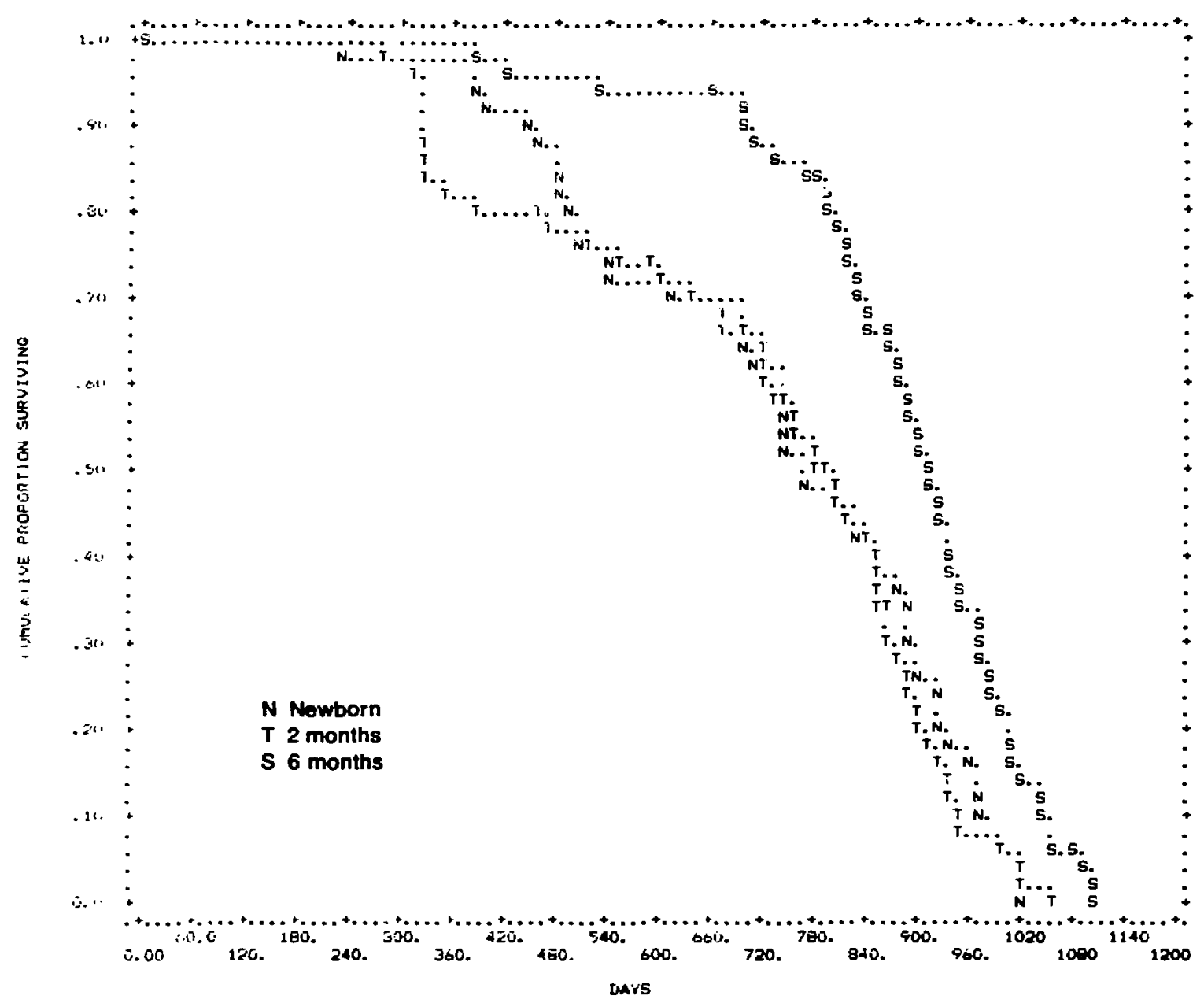

(a)

Fig. 3. (a)-(c). Cumulative proportion of conerol mice in specific age groups surviving past 450 days. 


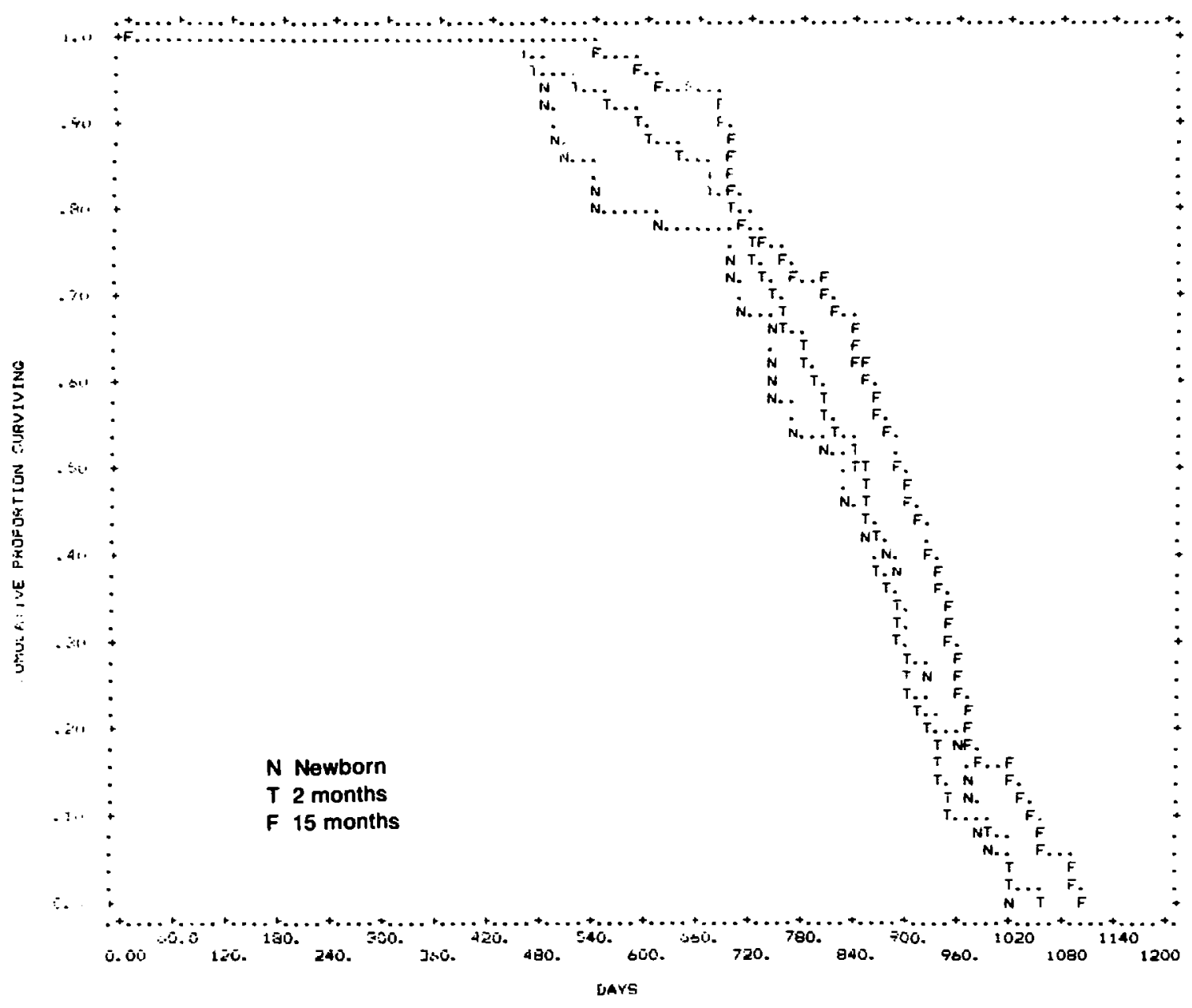

(b)

Fig. 3. (cont) 


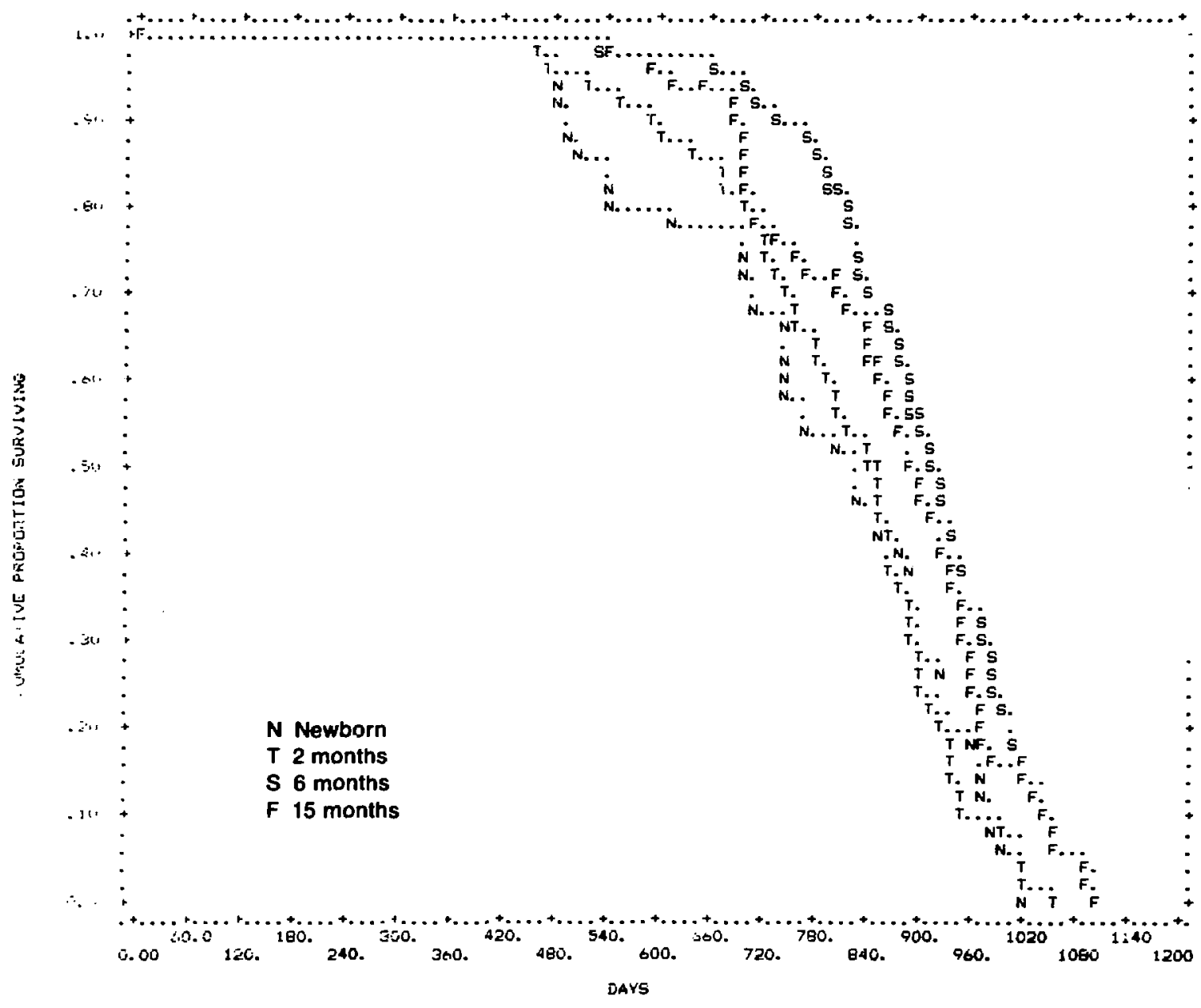

(c)

Fig. 3. (cont) 